bioRxiv preprint doi: https://doi.org/10.1101/2020.07.21.214973; this version posted July 21, 2020. The copyright holder for this preprint (which

was not certified by peer review) is the author/funder, who has granted bioRxiv a license to display the preprint in perpetuity. It is made available under aCC-BY-NC-ND 4.0 International license.

\title{
Calretinin and calbindin architecture of the midline thalamus associated with prefrontal- hippocampal circuitry
}

\author{
Abbreviated Title: CALCIUM BINDING PROTEINS IN MIDLINE THALAMUS \\ Tatiana D. Viena ${ }^{1}$, Gabriela E. Rasch ${ }^{1}$, Daniela Silva ${ }^{1}$, Timothy A. Allen ${ }^{1,2^{*}}$ \\ ${ }^{1}$ Cognitive Neuroscience Program, Department of Psychology, Florida International University, Miami, FL, \\ 33199, USA \\ ${ }^{2}$ Department of Environmental Health Sciences, Robert Stempel College of Public Health, Florida \\ International University, Miami, FL, 33199, USA
}

Keywords: calretinin, calbindin, parvalbumin, nucleus reuniens, paratenial, rhomboid, paraventricular nucleus

Number of figures: 7

Number of tables: 0

Number of text pages: 46

Number of supplemental figures: 1

Number of supplemental tables: 2

Total character count (with spaces):

Title: 110

Abstract: 2057

Introduction: 6801

Results: 23,008

Discussion: 11,447

Acknowledgement: 388

Author Contributions: 181

Figure Captions: 11,034

Total: 55,025

Corresponding Author:

Timothy A. Allen, PhD

Department of Psychology

Florida International University

11200 SW $8^{\text {th }}$ Street

Miami, FL, 33199

email: tallen@fiu.edu

Website: http://allenlab.fiu.edu/

Twitter: @AllenNeuroLab

Conflicts of Interest: None. 
bioRxiv preprint doi: https://doi.org/10.1101/2020.07.21.214973; this version posted July 21, 2020. The copyright holder for this preprint (which

was not certified by peer review) is the author/funder, who has granted bioRxiv a license to display the preprint in perpetuity. It is made available under aCC-BY-NC-ND 4.0 International license.

CALCIUM BINDING PROTEINS IN MIDLINE THALAMUS

\section{Authors Contributions}

TDV and TAA designed experiments; TDV, GER, and DS performed research; TDV drafted the manuscript; TDV and GER analyzed the results; and TDV, GER, DS, and TAA edited the manuscript.

\section{Acknowledgements}

The authors would like to thank Amanda Pacheco-Spiewak and Nashya Linares for their assistance in cell counting; Maanasa Jayachandran and Maximilian Schlecht for experimental assistance; and Jennifer Dziedzic and Tomás Guilarte for help with microscopy. This work was supported, in part, by NIH grant $\mathrm{MH} 113626$ to TAA, and funds from the FIU CASE Distinguished Postdoctoral Program to TDV. 
ABSTRACT

68 The midline thalamus bi-directionally connects the medial prefrontal cortex (mPFC) and hippocampus

69 (HC) creating a unique cortico-thalamo-cortico circuit fundamental to memory and executive function.

70 While the anatomical connectivity of midline thalamus has been thoroughly investigated, little is known

71 about its cellular organization within each nucleus. Here we used immunohistological techniques to

72 examine cellular distributions in the midline thalamus based on the calcium binding proteins parvalbumin

73 (PV), calretinin (CR), and calbindin (CB). We also examined these calcium binding proteins in a

population of reuniens cells known to project to both mPFC and $\mathrm{HC}$ using a dual fluorescence retrograde

adenoassociated virus (AAV) based tracing approach. These dual reuniens mPFC-HC projecting cells, in particular, are thought to be important for synchronizing mPFC and $\mathrm{HC}$ activity. First, we confirmed the absence of $\mathrm{PV}^{+}$neurons in the midline thalamus. Second, we found a common pattern of $\mathrm{CR}^{+}$and $\mathrm{CB}^{+}$ cells throughout midline thalamus with $\mathrm{CR}^{+}$cells running along the nearby third ventricle (3V) and penetrating the midline. $\mathrm{CB}^{+}$cells were consistently more lateral and toward the middle of the dorsalventral extent of the midline thalamus. Notably, single-labeled $\mathrm{CR}^{+}$and $\mathrm{CB}^{+}$zones were partially overlapping and included dual-labeled $\mathrm{CR}^{+} / \mathrm{CB}^{+}$cells. Within $\mathrm{RE}$, we also observed a $\mathrm{CR}$ and $\mathrm{CB}$ subzone specific diversity. Interestingly, dual mPFC-HC projecting neurons in RE expressed none of the calcium binding proteins examined, but were contained in nests of $\mathrm{CR}^{+}$and $\mathrm{CB}^{+}$cells. Overall, the midline thalamus was well organized into $\mathrm{CR}^{+}$and $\mathrm{CB}^{+}$rich zones distributed throughout the region, with dual mPFC-HC projecting cells in reuniens representing a unique cell population. These results provide a cytoarchitectural organization in the midline thalamus based on calcium binding protein expression, and sets the stage for future cell-type specific interrogations of the functional role of these different cell populations in mPFC-HC interactions. 
bioRxiv preprint doi: https://doi.org/10.1101/2020.07.21.214973; this version posted July 21, 2020. The copyright holder for this preprint (which

was not certified by peer review) is the author/funder, who has granted bioRxiv a license to display the preprint in perpetuity. It is made available under aCC-BY-NC-ND 4.0 International license.

\section{INTRODUCTION}

Interactions between the rodent agranular medial prefrontal cortex (mPFC) and the hippocampus $(\mathrm{HC})$ are essential to cognition and adaptive behavior, especially the flexible use and consolidation of memory (Churchwell \& Kesner, 2011; Eichenbaum, 2017; Jin \& Maren, 2015; McGaugh et al., 2019; Preston \& Eichenbaum, 2013). Theoretically, mPFC-HC dysfunction is a common root cause of various often overlapping neurocognitive symptoms that define several mental health disorders including Alzheimer's disease (Braak \& Braak, 1991), schizophrenia (Lisman et al., 2010), epilepsy (Gelinas et al., 2016), and others. Anatomically, mPFC-HC interactions occur through multiple circuits including direct ventral HC $\rightarrow$ mPFC projections (Cenquizca \& Swanson, 2007; Ferino et al., 1987; Skelin et al., 2019;

Spellman et al., 2015); indirect cortico-cortico pathways via entorhinal (Burwell, 2000; Kerr et al., 2007; Witter et al., 2017), perirhinal cortex (Furtak et al., 2007; Jayachandran et al., 2019) and retrosplenial cortex (Hunsaker \& Kesner, 2018; Nelson et al., 2014); and through midline thalamo-cortical connections (Hoover \& Vertes, 2012; Vertes et al., 2007, 2015). In this regard, the midline thalamus is unique in that it serves a fundamental role in creating the canonical higher-order cortico-thalamo-cortico circuitry that unites mPFC with the HC (Sherman, 2017; Dolleman-van der Weel et al., 2019).

Major subdivisions of the midline thalamus include the dorsally situated paraventricular (PVT) and parataenial $(\mathrm{PT})$ nuclei, and the ventrally situated rhomboid $(\mathrm{RH})$ and reuniens $(\mathrm{RE})$. Each region has unique connectivity patterns with mPFC, the $\mathrm{HC}$, entorhinal and perirhinal cortex and septum, and including special dual mPFC-HC projecting neurons (Su \& Bentivoglio, 1990; Varela et al., 2014; Vertes et al., 2006; Vertes \& Hoover, 2008). Specific anatomical connectivity patterns have been the primary contributor in understanding and predicting subregional differences (Dolleman-van der Weel \& Witter, 1996; Vertes et al., 2006, 2015). For example, PVT has more connectivity with the amygdala (Li \& Kirouac, 2008; Su \& Bentivoglio, 1990) and been related to adaptive fear memory (Choi \& McNally, 2017; Penzo et al., 2015). While RE, the most studied region, contains numerous cells with bidirectional monosynaptic projections to CA1 and mPFC (Hoover \& Vertes, 2012; Varela et al., 2014), and thus been related to memory consolidation (Barker \& Warburton, 2018; Dolleman-van der Weel et al., 2019; Varela 
116 et al., 2014), top-down memory functions (Ito et al., 2015; Jayachandran et al., 2019; Viena et al., 2018;

117 Xu \& Sudhof, 2013), and mPFC-HC synchrony (Ferraris et al., 2018; Hallock et al., 2016; Hauer et al.,

118 2019; Roy et al., 2017)

119 Little is known about the organization of cell types in the midline thalamus. Recently, Lara-

120 Vasquez et al. (2016) identified two populations of midline thalamic cells that were differentiated by their

121 calcium binding protein expression, notably and calretinin (CR) and calbindin (CB). Calcium binding

122 proteins regulate several extra- and intra-cellular functions such as cell-cell communication, cell

123 contracture, and signal transduction by triggering or buffering calcium signaling and compartmental

124 concentrations (Arai et al., 1994; Celio, 1990; del Río \& DeFelipe, 1996; Fonseca \& Soriano, 1995;

125 Sloviter, 1989; Zimmer et al., 1995). Lara-Vazquez et al. (2016) went on to show that the in vivo activity of

126 midline thalamic neurons were determined, in part, by their calcium binding protein expression.

127 Specifically, they showed that (during urethane anesthesia) midline thalamic $\mathrm{CR}^{+}$cells fired at low rates,

128 did not increase their activity during $\mathrm{HC}$ theta, and were inhibited during $\mathrm{HC}$ sharp-wave ripples.

129 Conversely, $\mathrm{CR}^{-}$cells fired faster and responded to $\mathrm{HC}$ theta.

130 In the rat brain, the anatomical distribution of calcium binding proteins, including parvalbumin (PV),

$131 \mathrm{CR}$ and $\mathrm{CB}$, differ widely across brain regions. For example, in the neocortex, $\mathrm{PV}$ positive $\left(\mathrm{PV}^{+}\right)$and $\mathrm{CB}^{+}$

132 neurons are found throughout layers II-V, while CR positive $\left(\mathrm{CR}^{+}\right)$cells are mainly found in superficial

133 cortical layers (Condé et al., 1994; DeFelipe, 1997; Hof et al., 1999; Reynolds et al., 2004; Sloviter, 1989).

134 In the $\mathrm{HC}, \mathrm{PV}^{+}$neurons can be found in restricted layers and neuronal types in $\mathrm{CA} 1$ and $\mathrm{CA} 3$ such as

135 non-pyramidal basket and axo-axonic cells, while $\mathrm{CB}^{+}$cells are localized in CA1 and CA2 (Kosaka et al.,

136 1988; Aika et al., 1994; Fonseca and Soriano, 1995; Fuchs et al., 2007), and CR ${ }^{+}$neurons preferentially

137 stain interneurons in CA1 (Miettinen et al., 1992; del Río and DeFelipe, 1996; Gulyás et al., 1996; Urbán

138 et al., 2002). In the thalamus, calcium binding protein distributions appear highly specific across nuclei.

139 Early studies showed that the midline thalamus labels particularly strongly for $\mathrm{CR}$ and $\mathrm{CB}$, but not PV

140 (Arai et al., 1994; Winsky et al., 1992). However, regional and sub-regional distributions of these calcium

141 binding proteins in the midline thalamus have not been explored in detail. 
bioRxiv preprint doi: https://doi.org/10.1101/2020.07.21.214973; this version posted July 21, 2020. The copyright holder for this preprint (which

was not certified by peer review) is the author/funder, who has granted bioRxiv a license to display the preprint in perpetuity. It is made available under aCC-BY-NC-ND 4.0 International license.

CALCIUM BINDING PROTEINS IN MIDLINE THALAMUS

Specifying the expression and topography of calcium binding proteins in midline thalamus will

143 provide novel insights into structure and provide opportunities for cell-type specific targeting. Here, we

144 used immunohistological techniques to label and analyze details of the distribution PV, CR and CB

145 throughout the midline thalamus. We also targeted calcium binding protein expression specifically in

146 populations of RE cells that project to both $\mathrm{MPFC}$ and $\mathrm{HC}$ using dual retrograde viral tracers, in

147 combination with immunohistochemistry. Our results first confirmed the absence of $\mathrm{PV}^{+}$cells throughout

148 the midline thalamus. Second, we showed that there are distinct functional zones in midline thalamus

149 defined by the topography of $\mathrm{CR}^{+}$and $\mathrm{CB}^{+}$labeling. Notably, we observed that the pattern of $\mathrm{CR}^{+}$and $\mathrm{CB}^{+}$

150 zones were well matched between dorsal midline thalamus (PVT and PT) and ventral midline thalamus

151 (RH and RE), only they were inverted relative to each other reflecting their wrapping around with the third

152 ventricle $(3 \mathrm{~V}) . \mathrm{CR}^{+}$zones were most dense medial-laterally against the dorsal or ventral $3 \mathrm{~V}$ walls and ran

153 dorso-ventrally, or ventro-medially, along the midline away from their respective $3 \mathrm{~V} . \mathrm{CB}^{+}$cells were

154 clustered more ventro- or dorso-laterally (for dorsal and ventral midline thalamus, respectively). $\mathrm{CR}^{+}$and

$155 \mathrm{CB}^{+}$zones also overlapped and contained dual-labeled $\mathrm{CR}^{+} / \mathrm{CB}^{+}$cells. Lastly, we show that dual mPFC-

$156 \mathrm{HC}$ projecting cells in RE expressed none of the three calcium binding proteins examined ( $P V, C R$, and

157 CB) but were surrounded by dense nests of $\mathrm{CR}^{+}$and $\mathrm{CB}^{+}$cells. We discuss these results with respect to

158 the mPFC-HC circuitry, and the implications of future functional interrogations of the midline thalamus.

MATERIALS AND METHODS

161 Animal care and use

162 All procedures described were conducted in compliance with Florida International University (FIU)

163 Institutional Animal Care and Use Committee (IACUC) and Institutional Biosafety Committee (IBC). Brain

164 tissue sections (40- $\mu \mathrm{m}$ thick) from a total of 16 Long Evans rats (14 males, 2 females; Charles River; 250 -

$165350 \mathrm{~g}$ on arrival) were used in these experiments. Rats were housed individually in a 12 hours inverse

166 light/dark cycle (lights off at 10 a.m.) and had ad libitum access to food and water. 
A subsample of rats ( $n=4,2$ males and 2 females) received bilateral retrograde AAV-CAG-

TdTomato (59462-AAV rg; Addgene, MA) in mPFC (PL/IL) at the following DV coordinates: $-5.0 \mathrm{~mm}(50 \mathrm{~nL})$,

-4.4mm (150 nL), and -3.8mm (200 nL), and AAV-CAG-GFP (Addgene, MA; 37825-AAV $\mathrm{rg}_{\text {g }}$ targeting vCA1

at $-7.2 \mathrm{~mm}(100 \mathrm{~nL}), 6.8 \mathrm{~mm}(200 \mathrm{~nL})$, and $6.2 \mathrm{~mm}(200 \mathrm{~nL})$. Retrograde viral vector expression post

injections was between 6-8 weeks before animals were sacrificed. Thalamic brain tissue sections from

173 these rats further underwent 3,3'-diaminobenzidine (DAB) reactions of CR or CB (see below) prior to

image visualization and captures using an Olympus BX41 brightfield/epifluorescence microscope.

\section{Immunohistochemical tissue processing}

Naïve and experimental rats were deeply anesthetized and transcardially perfused with $100 \mathrm{~mL}$ of heparin saline at a speed of $10 \mathrm{~mL} /$ minute, followed by $250 \mathrm{~mL}$ of $4 \%$ paraformaldehyde (PFA, $\mathrm{pH} 7.4)$ at the same perfusion speed. Post perfusion, brains were removed, preserved in 4\% PFA for 24 hours and then cryoprotected in $30 \%$ sucrose solution until they sank to the bottom. Subsequently, fixated brains were frozen and cut into coronal sections using a cryostat (Leica CM 3050S) or a sliding microtome.

All tissue sections were cleaned with $1 \%$ sodium-borohydride in $0.1 \mathrm{M} \mathrm{PB}(\mathrm{pH} 7.4)$, blocked for 1 hour in $0.5 \%$ Bovine Serum Album (BSA) and then processed using the following procedures:

\section{Parvalbumin fluorescence reactions}

A set of thalamic brain sections from 4 male rats was incubated at room temperature for 48 hours in parvalbumin (PV) primary antibody (1:250, MCA-3C9; Encore Bio, FL). After washes, tissue was incubated for 5 hours at room temperature in VectaFluor DyLight 594 anti-mouse secondary antibody (3 drops in $5 \mathrm{~mL}$ of $0.1 \%$ BSA, DK-8818; Vector Labs, CA). When incubation was completed, tissue was washed in $0.1 \mathrm{M} \mathrm{PB}(3 \times 5$ minutes $)$ then mounted on gelatin coated slides and coverslipped with VectaShield mounting medium with DAPI for visualization.

\section{Calretinin and calbindin dual fluorescence reactions}

Thalamic brain tissue sections from 5 male rats were incubated for 48 hours at room temperature in mouse CB primary antibody (1:500, MCA-5A9; Encore Bio, FL) and 24 hours in rabbit CR primary antibody (1: 2000, RPCA-Calret; Encore Bio, FL). After washes (3 x 5 minutes), sections were incubated 
bioRxiv preprint doi: https://doi.org/10.1101/2020.07.21.214973; this version posted July 21, 2020. The copyright holder for this preprint (which

was not certified by peer review) is the author/funder, who has granted bioRxiv a license to display the preprint in perpetuity. It is made available under aCC-BY-NC-ND 4.0 International license.

CALCIUM BINDING PROTEINS IN MIDLINE THALAMUS

194 in secondary antibodies Alexa Flour 488 (anti-mouse, 1:1000) for 6 hours and Alexa Flour 594 (anti-

195 rabbit, 1:1000) for 3 hours at room temperature. Post incubation, sections underwent PB washes and

196 then, sections were treated with Vector TrueVIEW Autofluorescence kit (SP-8400; Vector Labs, CA; 3

197 cases) for 2 minutes at room temperature to remove any background from aldehydes. After this step,

198 tissue was washed 3 times with PB and subsequently, mounted in gelatin coated slides and coverslipped

199 with VectaShield mounting medium with DAPI.

200 Calretinin $\left(C R^{+}\right)$and calbindin $\left(C B^{+}\right) D A B$ reactions

Brain sections that included midline thalamus were incubated for 48 hours at room temperature in

rabbit calretinin (CR) primary antibody (1:2000, RPCA-Calret; Encore Bio, FL) OR mouse calbindin (CB)

primary antibody (1:500, MCA-5A9; Encore Bio, $F L)$ in $5 \mathrm{~mL}$ of $0.1 \%$ BSA. After this period, tissue was

washed 3 times for 5 minutes in $0.1 \mathrm{M} \mathrm{PB}$ and placed in goat anti-rabbit OR anti-mouse biotinylated

secondary antibodies respectively (1:500, BP-9200/9100; Vector Labs, CA) for 6 hours. After PB washes,

the tissue was reacted in a solution containing avidin-biotin complex (Vectastain Elite ABC Kit, PK-6100;

207 Vector Laboratories, CA) for one hour at room temperature, followed by three 5-minute rinses in $0.1 \mathrm{M}$

208 PB. The peroxidase reaction was produced by incubating the sections for 5 to 12 minutes in a DAB

209 substrate solution (SK-4100; Vector Labs, CA). Reacted tissue was then mounted on gelatin coated

210 slides, dehydrated in methanol and xylene before being cover-slipped with Permount or Vectashield

211 antifade mounting medium with DAPI (H-1900, Vector Labs, CA).

\section{Imaging and data analysis}

213 For each subject, sections were imaged at different rostro-caudal levels of midline thalamus ( $\beta$

214 range -1.08/-3.0). Cases with similar rostral, mid and caudal levels were grouped together for cell

215 quantification across reactions, nuclei and levels. Schematic drawings (overlays) from Swanson Rat Brain

216 Atlas (2018) were used to define the boundaries of the thalamic nuclei. The regions were quantified

217 automatically (see below) to identify immunoreacted cell bodies at each of the selected brain levels. Atlas

218 overlays were placed on top of original captures using Adobe Illustrator ${ }^{\circledR}$ (Adobe Systems Inc., San 
219 Jose, CA). Cell quantification was done on one hemisphere based on overall quality to avoid intrinsic

220 confounds such as large blood vessels that might be present in any one section.

221 Immunofluorescence from $\mathrm{PV}^{+}, \mathrm{CB}^{+}$and $\mathrm{CR}^{+}$tissue, and retrogradely labeled $\mathrm{RE}$ neurons from

222 mPFC and HC injections, was imaged using an Olympus FV1200 confocal microscope at 10X, 20X and

223 60X focusing on midline thalamic structures (PVT, PT, RH and RE) using standard filter cubes for red

224 fluorescence (excitation 545nm, emission 605nm), green fluorescence (excitation 470nm, emission

225 525nm) and DAPI (excitation 350nm, emission 460nm). Captures at 60X magnification (oil immersed)

226 were obtained to further explore and verify cell body staining. DAB peroxidase stained sections were

227 captured using an Olympus BX51 brightfield microscope at 20X magnification.

228 Automated cell counts

Quantification of neurons in all thalamic regions of interest (ROI) was performed using a

customized automated pipeline built in CellProfiler Software version 3.1.9 (cellprofiler.org) for objective

231 cell counts. FIJI ImageJ (Version 2.0.0; NIH; Schindelin et al., 2012) was used for preprocessing. The

232 data was extracted from CellProfiler using customized Python code through Anaconda Software (Version

233 2-2.4.0). CellProfiler has been previously used and validated for both fluorescence and chromogenic

234 localization by other research laboratories (McQuin et al., 2018; Tollemar et al., 2018). We further

235 validated the accuracy of CellProfiler by comparing the counts from 26 ROls between two experienced

236 counters (manually) and CellProfiler. The counts from Experimenter 1 and Experimenter 2, and their

237 combined average were significantly correlated with the results yielded by CellProfiler (CellProfiler v.

238 Experimenter 1, $r=.0 .956$; CellProfiler v. Experimenter 2, $r=0.941$; CellProfiler v. Average, $r=0.958$; all

$239 p<.001)$. A test of inter-rater reliability showed a very high degree of reliability (Cronbach's $\alpha=9.78)$

240 between the counters total average and CellProfiler's results.

241 Fluorescence-based $\mathrm{PV}^{+}, \mathrm{CR}^{+}$and $\mathrm{CB}^{+}$cell counts (single/dual)

A pipeline was created for the quantification of $\mathrm{PV}^{+}, \mathrm{CB}^{+}, \mathrm{CR}^{+}$or DAPI fluorescence-based cell

counts. CorrectIlluminationCalculate and CorrectIlluminationApply functions from CellProfiler were applied

244 onto separated RGB images in order to correct any uneven lighting artifacts and further reduce noise. The 
bioRxiv preprint doi: https://doi.org/10.1101/2020.07.21.214973; this version posted July 21, 2020. The copyright holder for this preprint (which

was not certified by peer review) is the author/funder, who has granted bioRxiv a license to display the preprint in perpetuity. It is made available under aCC-BY-NC-ND 4.0 International license.

CALCIUM BINDING PROTEINS IN MIDLINE THALAMUS

245 three channels were aligned based on the signal intensity values using the CellProfiler Align function. A

246 restricted range of diameters and a set of intensity values were determined for each channel allowing for

247 proper cell identification. A mask of the identified cells was created for each RGB channel. Dual-labeled

$248 \mathrm{CR}^{+} / \mathrm{CB}^{+}$cells were quantified by relating the masks to each other Using CellProfiler's Relate Objects

249 function.

$250 \quad D A B C R^{+}$and $C B^{+}$cell counts

A separate CellProfiler pipeline was created to quantify the number of $\mathrm{DAB}$ stained $\mathrm{CR}^{+}$and $\mathrm{CB}^{+}$

cells. ROls were isolated from overlayed brightfield images using Adobe Photoshop®. Brightfield images

were converted to a greyscale and inverted using the ImageMath function in CellProfiler. This process

helps reduce noise, enhance cell features, and makes it easier to identify non-cells bodies artifacts, thus

avoiding over-quantification. Quantification of cell bodies was determined with a set range of intensity and

256 diameter values.

257 Counting RE neurons with collaterals to MPFC and HC

We identified RE cell clusters that projected to both MPFC and HC with the FV1200 confocal

microscope with using a z-stack ( 0.5 microns optical sections) to confirm dual-labeling. The same tissue

was imaged with the Olympus BX41 brightfield-epifluorescence microscope for dual-fluorescence and

261 DAB imaging similar to previous reports (Al-Mashhadi et al., 2015; Majercikova et al., 2012; Young et al., 262 2005). Individual captures were made at 20X magnification for the following channels: red (RE $\rightarrow \mathrm{mPFC})$,

263 green $(\mathrm{RE} \rightarrow \mathrm{HC})$, blue (DAPI) and brightfield (DAB $C \mathrm{R}^{+}$or $\mathrm{DAB} C \mathrm{~B}^{+}$cells). Captures were made in two

264 prominent dorsal and ventral regions within a $545 \mu \mathrm{m} \times 390 \mu \mathrm{m}$ area that contained the dual-projecting

265 clusters in RE. The corresponding brightfield image of CR or CB was transposed onto the merged

266 fluorescent image using Adobe Photoshop ${ }^{\circledR}$. A separate layer was created to mark the location of $\mathrm{CR}^{+}$

267 cells with white '+' signs and $\mathrm{CB}^{+}$cells with cyan ' + ' signs. The flattened image was used to verify whether

268 there was an overlap between $\mathrm{DAB} \mathrm{CR}^{+}$or $\mathrm{DAB} \mathrm{CB}^{+}$cells with immunofluorescence reacted neurons.

269 Here, counts were performed manually by two experienced experimenters and averaged. DAPI cell

270 counts were done using a custom CellProfiler pipeline. 


\section{Cell soma (body) size}

Using $C R$ and $C B$ dual reacted immunofluorescence sections, we measured soma size $\left(\mu \mathrm{m}^{2}\right)$ in 273 PVT and RE using FIJI Image J. We sampled cells in a $200 \mu \mathrm{m} \times 200 \mu \mathrm{m}$ region of PVT and RE. Counts were made in medial, dorsolateral, and ventrolateral subregions of each nuclei. Cell bodies were outlined with the freehand tool in FIJI and measured using a set calibration scale from the microscope.

\section{Cell radius distance}

In merged fluorescent and brightfield images, the radial distance of $\mathrm{CR}^{+}$or $\mathrm{CB}^{+}$cells from a small sample of dual mPFC-HC cells in RE was measured by imposing a $100 \mu \mathrm{m}$ radius circle centered on each individual dual labeled cell. Then, the distance from the center of dual labeled cells to all $\mathrm{CR}^{+}$or $\mathrm{CB}^{+}$cells within this area was measured using Image $\mathrm{J}$.

\section{Statistical analysis}

For dual reacted $\mathrm{CB}$ and $\mathrm{CR}$ immunofluorescence data, two-way repeated measures analysis of

variance (ANOVAs) were performed to compare interaction or main effects of region (nuclei) and calcium binding protein expression type on cell area density across the rostro, medial and caudal levels, followed by one way-ANOVAs and multivariate/ pairwise comparisons (with Bonferroni correction) when the differences were statistically significant. For DAB reacted tissue, two-way ANOVAs were used to compare region (nuclei) and calcium binding protein expression type differences on cell area density. When

significant, Bonferroni post hoc tests and pairwise comparisons followed. Effect size was performed using

Hedges'd given the unequal sample sizes. Finally, a linear regression analysis was performed to assess

the relationship between DAB cell counts and distance from dual projecting cells. All collected data was 291 tallied and saved in Microsoft Excel and subsequently analyzed in SPSS (version 26). An alpha of 0.05 292 was considered statistically significant for all analysis.

\section{RESULTS}

\section{Absence of $\mathrm{PV}^{+}$cells in midline thalamus}


297 length of the midline thalamus ( $n=4$ rats, 12 coronal sections)(Fig. 1A-C). The lack of PV expression in

298 midline thalamic cells stood in stark contrast to prominent $\mathrm{PV}^{+}$cell body labeling in other brain regions

299 with well-established $\mathrm{PV}^{+}$cell populations including the thalamic reticular nucleus of the thalamus (TRN),

300 the hippocampus, lateral and basolateral amygdala, striatum, and cortex (Fig. 1A, D-E). We also

301 observed dense $\mathrm{PV}^{+}$fibers and puncta throughout much of the nearby lateral thalamus and striatum. In

302 TRN, we saw uniformly dense populations of $\mathrm{PV}^{+}$cells with large immunonegative nuclei, which is

303 characteristic of $\mathrm{PV}^{+}$labeling in TRN neurons (Fig 1D;(Arai et al., 1994; Celio, 1990; Csillik et al., 2005;

304 Kirichenko et al., 2017). Likewise, the distribution of $\mathrm{PV}^{+}$cells in cortex was organized by layers and was

305 comparatively more sparse (Fig 1E; also see Van Brederode et al., 1991; Ahn et al., 2017). Despite the

306 absence of $\mathrm{PV}^{+}$cell bodies in the midline thalamus, parvalbumin labeling was still abundant in the form of

$307 \mathrm{PV}^{+}$puncta that were most often clustered near or between cell bodies (Fig. 1B-C, insets). In some cases,

$308 \mathrm{PV}^{+}$puncta were observed enveloping entire cell bodies. More commonly, $\mathrm{PV}^{+}$puncta formed

309 asymmetrical cluster densities that were biased toward one pole and formed a rough spherical cap.

310 Generally, the observations are in line with previous descriptions of $\mathrm{PV}^{+}$labeling in midline thalamus

311 (Celio, 1990; Arai et al., 1994).

312 CR and CB expression in midline thalamus

313 Next we examined $\mathrm{CR}^{+}$and $\mathrm{CB}^{+}$labeling in three rostral-caudal sections because of known

314 differences along this axis of the midline thalamus (Arai et al., 1994; Celio, 1990; Rogers \& Résibois,

315 1992; Winsky et al., 1992). Each coronal section was immunofluorescence reacted for both CR and CB. A

316 general finding was that $\mathrm{CR}^{+}$and $\mathrm{CB}^{+}$cell distributions show different clustering zones within and

317 between PVT, PT, RE and RH. A clear overall pattern emerged in the $\mathrm{CR}^{+}$and $\mathrm{CB}^{+}$labeling that similarly

318 organized the cytoarchitecture of the dorsal midline thalamus (PVT and PT) and ventral midline thalamus

319 (RH and $\mathrm{RE})$. That is, $\mathrm{CR}^{+}$zones were dense medial-laterally against the dorsal and ventral $3 \mathrm{~V}$ and ran

320 dorso-ventrally along the midline away from their respective $3 \mathrm{~V}$ forming the shape of a "T" or " $\mathrm{Y}$ " in dorsal

321 midline thalamus, or a similar inverted pattern in ventral midline thalamus. In relation to $\mathrm{CR}^{+}$cells, $\mathrm{CB}^{+}$

322 cells were clustered more ventro- or dorso-laterally (for dorsal and ventral midline thalamus, respectively). 
$323 \mathrm{CR}^{+}$and $\mathrm{CB}^{+}$zones partially overlapped and contained dual-labeled $\mathrm{CR}^{+} / \mathrm{CB}^{+}$cells. Although these $\mathrm{CR}^{+}$

324 and $\mathrm{CB}^{+}$patterns were similar in dorsal and ventral midline thalamus, there was generally more

325 complexity to this organization in ventral midline thalamus.

\section{$326 \mathrm{CR}^{+}$and $\mathrm{CB}^{+}$labeling distributions in rostral midline thalamus}

In rostral sections $\left(\beta-1.44 ; n=4\right.$ rats), $C R^{+}$cell and fibers densities were found in several regions including the hypothalamus, striatum, central and medial amygdala, medial divisions of thalamus, and cortex (Fig. 2A, magenta) notably including a very prominent $\mathrm{CR}^{+}$fiber band in the superficial layers of entorhinal cortex (Wouterlood et al., 2001). In the midline thalamus, $\mathrm{CR}^{+}$cells were predominantly located

331 in the dorsal, medial and ventral portions (Fig. 2B \& C, magenta). Whereas, $\mathrm{CB}^{+}$cells and fibers often expressed in the same regions as $\mathrm{CR}^{+}$cells, labeling was more prominent in the lateral portions of the 333 thalamus, internal capsule, basolateral amygdala, and globus pallidus (Fig. 2A, green). In the midline 334 thalamus, $\mathrm{CB}^{+}$cells chiefly labeled the lateral portions (Fig. 2B \& C). Generally, we observed that $\mathrm{CR}^{+}$ 335 and $\mathrm{CB}^{+}$cell distributions organized into well-defined zones within the midline thalamus giving the 336 impression that there are important calcium binding protein specific subregions within PVT, PT and RE.

\section{Distinctive $\mathrm{CR}^{+}$and $\mathrm{CB}^{+}$labeling in rostral PVT and PT}

Next, we focused on $\mathrm{CR}^{+}$and $\mathrm{CB}^{+}$labeling in the dorsal midline thalamic nuclei (PVT and PT; Fig.

339 2B). While PVT and PT are often considered together, their $\mathrm{CR}^{+}$and $\mathrm{CB}^{+}$cell distributions indicated that 340 they contain different functional zones. In PVT, $\mathrm{CR}^{+}$cells were bright, large, and clustered together in a 341 chain formation that ran dorsoventrally and hugged the lateral borders $(M=9.168, S D=1.146$; density in 342 cells per $0.01 \mathrm{~mm}^{2}$; Fig. $2 \mathrm{~B} \& \mathrm{D}_{\mathrm{i}}$ ). By contrast, few $\mathrm{CR}^{+}$cells were visible in dorsal and medial PVT, 343 although these areas were heavily populated with $\mathrm{CR}^{+}$puncta. $\mathrm{CB}^{+}$cells stained much lighter, but 344 exhibited similar topography within PVT $\left(M=5.928, S D=1.490\right.$; density in cells per $0.01 \mathrm{~mm}^{2} ;$ Fig. 2B \& $345 \mathrm{D}_{\mathrm{ii}}$ ). Dual-labeled $\mathrm{CR}^{+}$and $\mathrm{CB}^{+}$cells were most prominent in the lateral portions of PVT (Fig. 2C \& $\mathrm{D}_{\mathrm{iii}}$ ). 346 These dual-labeled $\mathrm{CR}^{+} / \mathrm{CB}^{+}$cells accounted for $29.22 \%$ of $\mathrm{CR}^{+}$cells and $45.19 \%$ of $\mathrm{CB}^{+}$cells in PVT 347 (Fig. 2F). 
Different from PVT, PT had a clear segregation between $\mathrm{CB}^{+}$and $\mathrm{CR}^{+}$cell topographies (Fig. 2B).

In PT, $\mathrm{CR}^{+}$cells $\left(M=3.600, S D=1.978\right.$; density in cells per $\left.0.01 \mathrm{~mm}^{2}\right)$ were practically absent from

ventral PT but were abundant in dorsal PT. This $\mathrm{CR}^{+}$and $\mathrm{CB}^{+}$labeling delineates rostral PT into dorsal

351 and ventral subregions (Fig $2 \mathrm{~B}) . \mathrm{CB}^{+}$cells $\left(M=8.845, S D=4.847\right.$; density in cells per $\left.0.01 \mathrm{~mm}^{2}\right)$ were

observed throughout PT, usually intermingled or overlapping with $\mathrm{CR}^{+}$cells in dorsal PT, or as an

353 independent population in ventral $\mathrm{PT}$. Dual-labeled $\mathrm{CR}^{+} / \mathrm{CB}^{+}$cells $(M=2.398, S D=2.086$; density in cells

per $0.01 \mathrm{~mm}^{2}$ ) were located in dorsal PT. $\mathrm{CR}^{+} / \mathrm{CB}^{+}$cells accounted for $66.67 \%$ of $\mathrm{CR}^{+}$cells and $27.12 \%$ of

$\mathrm{CB}^{+}$cells in $\mathrm{PT}$.

Rostral RE exhibits $\mathrm{CR}^{+}$and $\mathrm{CB}^{+}$defined zones

In rostral sections, the ventral midline thalamus is composed entirely of RE, which showed intensity increased from dorsal to ventral borders $\left(M=7.990, S D=1.042\right.$; density in cells per $\left.0.01 \mathrm{~mm}^{2}\right)$.

Generally, $\mathrm{CR}^{+}$cells in rostral RE were concentrated in dorsal, middle, and ventral regions and practically avoided lateral areas, with the exception of a few cells that dual-labeled with $\mathrm{CB}^{+}$cells (Fig. $2 \mathrm{C} \& \mathrm{E}$ ). RE $\mathrm{CB}^{+}$cells $\left(M=11.383, S D=2.404\right.$; density in cells per $\left.0.01 \mathrm{~mm}^{2}\right)$ were present throughout the whole body of $\mathrm{RE}$ but were more densely packed and separated from $\mathrm{CR}^{+}$cells in dorsolateral regions. In dorsal and medial RE, $\mathrm{CR}^{+}$and $\mathrm{CB}^{+}$cells were loosely distributed throughout and cells were visibly smaller in size compared to cells in the dorsolateral regions (Fig. 2C, $\mathrm{E}_{\mathrm{i}}-\mathrm{E}_{\mathrm{ii}}$; Table S1). Patches of dual-labeled $\mathrm{CR}^{+} / \mathrm{CB}^{+}$ 
PVT and RE show opposing $C R^{+}, C B^{+}$and $C R^{+} / C B^{+}$cell densities and cell size patterns in rostral

374 RE

Next we focused on comparing PVT and RE, the largest and most studied regions of midline thalamus, which are well known for their different functional roles (Cassel et al., 2013; Hsu et al., 2014;

Kawano, 2001; Matzeu et al., 2014; Vertes et al., 2015). The overall $\mathrm{CR}^{+}$and $\mathrm{CB}^{+}$cell labeling patterns in rostral midline thalamus suggested clear differences between PVT and RE with more $\mathrm{CR}^{+}$cells in PVT and more $\mathrm{CB}^{+}$cells and dual-labeled $\mathrm{CR}^{+} / \mathrm{CB}^{+}$cells in RE. First, we compared $\mathrm{CR}^{+}$and $\mathrm{CB}^{+}$cell densities in PVT and RE. There was a significant effect of region $\left(F_{(1,3)}=32.773, p=0.011\right)$ such that $\mathrm{CB}^{+}$cell expressed $\left(F_{(1,3)}=0.004, p=0.955\right)$, and a significant interaction effect $\left(F_{(1,3)}=4.907, p=0.006\right)$, also significantly higher densities of dual-labeled $\mathrm{CR}^{+} / \mathrm{CB}^{+}$cells in RE than PVT (1.63:1, RE:PVT; pairedsamples $t_{(3)}=9.268, p=0.003$ ). A comparison of $\mathrm{CR}^{+}$and $\mathrm{CB}^{+}$cell sizes in PVT and RE (Fig. $2 \mathrm{G}$ ) showed no significant main effect of cell size by calcium binding protein expressed $\left(F_{(1,324)}=0.467, p=0.495\right)$ or region $\left(F_{(1,324)}=0.633, p=0.427\right)$, but there was a significant interaction effect $\left(F_{(1,324)}=5.404, p=0.021\right)$.

In PVT, $\mathrm{CR}^{+}$cells tended to be larger compared to $\mathrm{RE}$, and $\mathrm{CB}^{+}$cells were larger in RE compared to PVT

(Fig. 2G). Further in PVT, cells were largest laterally and smallest medially. In RE, $C B^{+}$cells were largest in dorsolateral subdivisions, but smaller in medial and ventrolateral divisions. Dual-labeled $\mathrm{CR}^{+} / \mathrm{CB}^{+}$cells 391 in PVT and RE were not significantly different (paired-samples $t_{(105)}=0.411, p=0.523$ ). Detailed cell size 392 measurements are provided in supplemental table S1.

$393 \mathrm{CR}^{+}$and $\mathrm{CB}^{+}$labeling in mid-levels of the midline thalamus

In mid-level sections $\left(\beta-1.78 ; n=5\right.$ rats), the overall $\mathrm{CR}^{+}$(Fig. 3A, magenta) and $\mathrm{CB}^{+}$(Fig. 3A,

green) cell and fiber densities were similarly distributed to the rostral levels. A notable change was more abundant $\mathrm{CR}^{+}$labeling in habenula, mediodorsal, anterodorsal and centromedial nuclei of the thalamus, 
more prominent in ventral midline thalamus, but $\mathrm{CR}^{+}$and $\mathrm{CB}^{+}$cells were found in all regions including PVT, PT, RE and RH to differing degrees (Fig. 3B \& C).

\section{Distinctive $\mathrm{CR}^{+}$and $\mathrm{CB}^{+}$cell labeling in PVT and PT at mid-levels of midline thalamus}

In mid-level coronal sections, PVT $\mathrm{CR}^{+}$cells were dense $(M=11.346, S D=3.771$, density in cells

per $0.01 \mathrm{~mm}^{2}$ ), bright, and packed together in large circular clusters located laterally (Fig. 3B). There was notably sparse cell labeling in dorsal PVT with extensive $\mathrm{CR}^{+}$puncta organized in dense fiber fields that often ran along the dorsal-ventral axis and thickened at the $3 \mathrm{~V}$ border. $\mathrm{CB}^{+}$cells were less dense $(M=$

\section{Distinctive $\mathrm{CR}^{+}$and $\mathrm{CB}^{+}$labeling in $\mathrm{RE}$ and $\mathrm{RH}$ at mid-levels of midline thalamus}

In mid-level sections, RE and $\mathrm{RH}$ showed distinctive patterns of $\mathrm{CR}^{+}$and $\mathrm{CB}^{+}$labeling (Fig. $3 \mathrm{C}$ ).

418 Compared to rostral levels, mid-level $R E C R^{+}$cells were bright and abundant $(M=8.910, S D=1.683$, 419 cells per $0.01 \mathrm{~mm}^{2}$ ) with a slight shift in location ventrally and laterally towards the early formation of RE 420 wings, and defined the lower border. $\mathrm{CR}^{+}$cells were also seen along the lateral borders of $\mathrm{RE}$, and 421 dorsomedially (Fig. $3 C)$. By comparison, $\mathrm{CB}^{+}$cells $\left(M=11.520 \mathrm{SD}=2.622\right.$, cells per $\left.0.01 \mathrm{~mm}^{2}\right)$, were localized throughout RE with independent (non-overlapping) populations in dorsal and dorsolateral regions. Notably at this level, $\mathrm{RE} \mathrm{CB}^{+}$cells in dorsolateral portions showed a very large cell body size that 
425 labeled $\mathrm{CR}^{+} / \mathrm{CB}^{+}$were mostly located along the lateral and ventral borders of $\mathrm{RE}$, and as patchy clusters 426 in centromedial and ventrolateral divisions of RE (Fig. $3 \mathrm{C}$ ). $\mathrm{CR}^{+} / \mathrm{CB}^{+}$cells accounted for $55.05 \%$ of $\mathrm{CR}^{+}$ 427 cells and $41.73 \%$ of $\mathrm{CB}^{+}$cells (Fig. $\left.3 \mathrm{E}_{\mathrm{iii}}-\mathrm{E}_{\mathrm{iv}}\right)$.

428 In RH, $\mathrm{CR}^{+}$cells were scarce $\left(M=1.760, S D=1.017\right.$, cells per $\left.0.01 \mathrm{~mm}^{2}\right)$, and presented similar 429 brightness and circular organization of that of PVT cells. $\mathrm{CR}^{+}$cells were primarily confined to medial $\mathrm{RH}$ 430 (Fig. 3C), with $\mathrm{CR}^{+}$fibers present laterally. By contrast, $\mathrm{CB}^{+}$cells were not bright but were plentiful 431 throughout $\mathrm{RH}\left(M=10.373, S D=2.703\right.$, cells per $\left.0.01 \mathrm{~mm}^{2}\right)$ with a tendency to cluster in lateral ends.

432 Dual-labeled $\mathrm{CR}^{+} / \mathrm{CB}^{+}$cells accounted for $50.71 \%$ of $\mathrm{CR}^{+}$cells and $8.60 \%$ of $\mathrm{CB}^{+}$cells.

433 Mid-level PVT and RE show opposing $C R^{+}, C B^{+}$, and $C R^{+} / C B^{+}$cell density and cell size patterns

In mid-levels, PVT and RE differences remained clear with PVT showing dominant $\mathrm{CR}^{+}$labeling

with $\mathrm{CB}^{+}$cells interspersed, and $\mathrm{RE}$ showing more $\mathrm{CB}^{+}$labeling dorsally and medially with $\mathrm{CR}^{+}$cell zones seen ventrally and laterally. We compared overall $\mathrm{CR}^{+}$and $\mathrm{CB}^{+}$cell densities in PVT and RE. There was no main effect of cell density by calcium binding protein expressed $\left(F_{(1,4)}=0.317, p=0.604\right)$ or region $\left(F_{(1,4)}=0.012, p=0.918\right)$, but there was a significant interaction effect $\left(F_{(1,4)}=8.702, p=0.042\right)$. As in rostral sections, mid-level PVT had relatively more $\mathrm{CR}^{+}$cells, and RE had more $\mathrm{CB}^{+}$cells (Fig. $3 \mathrm{~F}$ ). Unlike in rostral sections, there were no significant differences in the densities of dual-labeled $\mathrm{CR}^{+} / \mathrm{CB}^{+}$cells

441 (paired-samples $t_{(4)}=0.366, p=0.733$ ). A comparison of $\mathrm{CR}^{+}$and $\mathrm{CB}^{+}$cell sizes in PVT and RE (Fig. 3G) 442 showed no differences by calcium binding protein expression $\left(F_{(1,335)}=0.040, p=0.843\right)$, a significant 443 effect of region (PVT; $\left.F_{(1,335)}=6.406, p=0.012\right)$, and no significant interaction effect $\left(F_{(1,335)}=0.994, p=\right.$ 444 0.320). That is, PVT cells tended to be slightly larger (8.33\%) than RE (Fig. 3G \& Table S1).

$445 \mathrm{CR}^{+}$and $\mathrm{CB}^{+}$labeling distributions in caudal midline thalamus

In caudal sections $(\beta-2.76 ; n=4$ rats $)$, there were some notable variations in the overall 447 distribution of $\mathrm{CR}^{+}$and $\mathrm{CB}^{+}$labeling (Fig. 4A) including that $\mathrm{CR}^{+}$cell and fiber densities were now seen in 448 basolateral amygdala, and $\mathrm{CB}^{+}$staining increased in prominence in striatum. In midline thalamus, $\mathrm{CR}^{+}$ staining dorsally remained high (Fig. 4B). The balance of $\mathrm{CR}^{+}$and $\mathrm{CB}^{+}$labeling in ventral midline 
451 as compared to more rostral sections (Fig. 4C). Nuclei located centromedially in thalamus had numerous

$452 \mathrm{CB}^{+}$cells, while $\mathrm{CR}^{+}$cells were less abundant (Fig. 4A). As before, cells expressing both types of calcium 453 binding proteins were found in all midline thalamic structures examined in detail including PVT, RE, and

$454 \mathrm{RH}$.

\section{Caudal PVT $\mathrm{CR}^{+}$and $\mathrm{CB}^{+}$labeling}

In caudal PVT, expression of $\mathrm{CR}^{+}$cells $\left(M=10.950, S D=3.588\right.$, cells per $\left.0.01 \mathrm{~mm}^{2}\right)$ were bright

and clustered tightly just off the midline running along the dorsal/ventral axis, similar to more rostral sections (Fig. 4B). Dorsal PVT was absent of any cell labeling for CR or CB, but was dense with $\mathrm{CR}^{+}$

fibers. $\mathrm{CB}^{+}$cells $\left(M=8.935, S D=2.412\right.$, cells per $\left.0.01 \mathrm{~mm}^{2}\right)$ in caudal PVT lightly stained and were seen

throughout the structure. $\mathrm{CB}^{+}$cells were especially noticeable in the lateral and ventral portions (Fig 4B).

461 Dual-labeling $\mathrm{CR}^{+} / \mathrm{CB}^{+}$cells were prominent in dorsolateral areas accounting for $52.64 \%$ of $\mathrm{CR}^{+}$cells and $56.93 \%$ of $\mathrm{CB}^{+}$cells (Fig. 4Di-Div).

\section{Distinctive $\mathrm{CR}^{+}$and $\mathrm{CB}^{+}$labeling in $\mathrm{RE}, \mathrm{PRe}$, and $\mathrm{RH}$ in caudal midline thalamus}

In caudal sections, distinct topographical organizations of $\mathrm{CR}^{+}$and $\mathrm{CB}^{+}$cells emerged in $\mathrm{RH}, \mathrm{RE}$, and PRe. Caudal RE CR ${ }^{+}$cells $\left(M=10.560, S D=2.845\right.$, cells per $\left.0.01 \mathrm{~mm}^{2}\right)$ retained a bright color and

were mostly located dorsolaterally, unlike earlier rostro-caudal levels. The ventral portion of RE was

467 largely void of cells that labeled for either calcium binding protein. A network of $\mathrm{CR}^{+}$fibers located closed 468 to $3 \mathrm{~V}$, occupied most of this region along with a few $\mathrm{CR}^{+}$cells located laterally. (Fig. $4 \mathrm{C}$ ). $\mathrm{CR}^{+}$cell 469 expression was low in PRe (Fig. 4C), a structure known to be rich in RE neurons projecting to mPFC 470 (Cassel et al., 2013; Dolleman-van der Weel et al., 2019). RE CB ${ }^{+}$cells $(M=11.673, S D=3.106)$, cells 471 per $0.01 \mathrm{~mm}^{2}$ ) were seen prominently along the lateral borders, where they overlapped heavily with $\mathrm{CR}^{+}$

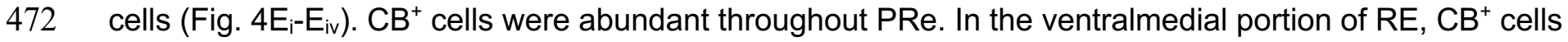
473 were few, small, and scattered (Fig. 4E; see Table S1). Dual-labeling $\mathrm{CR}^{+} / \mathrm{CB}^{+}$cells were seen throughout 474 the dorsal and medial subdivisions of $\mathrm{RE}$ and in $\mathrm{PRe} . \mathrm{CR}^{+} / \mathrm{CB}^{+}$cells accounted for $64.30 \%$ of $\mathrm{CR}^{+}$cells 
In caudal $\mathrm{RH}, \mathrm{CR}^{+}$were largely absent $\left(M=2.163, S D=1.368\right.$, cells per $\left.0.01 \mathrm{~mm}^{2}\right)$, while $\mathrm{CB}^{+}$

cells $\left(M=7.630, S D=5.344\right.$, cells per $\left.0.01 \mathrm{~mm}^{2}\right)$ were abundant and present through the region (Fig. $\left.4 \mathrm{C}\right)$.

$478 \mathrm{RH} \mathrm{CR}^{+}$cells were mainly located in the mediodorsal and medioventral borders of $\mathrm{RH}$, while $\mathrm{CB}^{+}$cells

479 were heavily distributed in the lateral wings with a relatively large size (Fig. $4 \mathrm{C}$ ). Dual-labeled $\mathrm{CR}^{+} / \mathrm{CB}^{+}$

480 expression accounted for $31.02 \%$ of $\mathrm{CR}^{+}$cells and $8.78 \%$ of $\mathrm{CB}^{+}$cells.

481 Caudal PVT and RE have different $C R^{+}, C B^{+}$, and $C R^{+} / C B^{+}$cell density and cell size patterns

In caudal midline thalamus, the overall pattern of $\mathrm{CR}^{+}$and $\mathrm{CB}^{+}$cell densities in PVT and RE

appeared to match well with more rostral sections. There were proportionally more $\mathrm{CR}^{+}$than $\mathrm{CB}^{+}$cells in

PVT, and more $\mathrm{CB}^{+}$than $\mathrm{CR}^{+}$cells in RE, although these differences were moderate (Fig. 4F). We

compared overall $\mathrm{CR}^{+}$and $\mathrm{CB}^{+}$cell densities in caudal PVT and RE. There was no main effect of calcium

binding protein expression $\left(F_{(1,3)}=0.542, p=0.515\right)$, or region $\left(F_{(1,3)}=0.519, p=0.523\right)$, but there was a

significant trend towards and interaction effect $\left(F_{(1,3)}=7.836, p=0.68\right)$. Similar to mid-level sections, there

was no significant difference in the proportion of dual-labeled $\mathrm{CR}^{+} / \mathrm{CB}^{+}$cells in PVT and RE (paired-

sample $\left.t_{(3)}=-1.258, p=0.297\right)$. A comparison of $\mathrm{CR}^{+}$and $\mathrm{CB}^{+}$cell sizes in caudal PVT and caudal RE

(Fig. 4G) showed no differences by calcium binding proteins $\left(F_{(1,310)}=1.996, p=0.159\right)$, no region effect

$491 \quad\left(F_{(1,310)}=1.265, p=0.262\right)$, and no interaction effect $\left(F_{(1,310)}=0.011, p=0.917\right)($ Fig. $4 G)$.

492 Distributions of $\mathrm{CR}^{+}$and $\mathrm{CB}^{+}$in $\mathrm{RE}$ subregions using 3,3'-Diaminobenzidine (DAB)

Notably, the results of the immunofluorescence experiments revealed topographically biased

494 clusters of $\mathrm{CR}^{+}$and $\mathrm{CB}^{+}$cell populations in RE, the largest of the midline thalamic nuclei (Arai et al., 1994;

495 Bokor et al., 2002; Winsky et al., 1992) that varied across the rostral-caudal axis. We further investigated

496 the distribution of $\mathrm{RE} \mathrm{CR}{ }^{+}$and $\mathrm{CB}^{+}$cells with $\mathrm{DAB}$ in all the $\mathrm{RE}$ internal subdivisions from those

497 established in Swanson brain atlas (2018) including five rostro-caudal levels of the rat's midline thalamus

498 ( $n=13$ rats, 7 CR and 6 CB) to confirm these patterns and densities. The results were entirely consistent

499 with the immunofluorescence in that all subregions of RE tended to have higher $\mathrm{CB}^{+}$cell area densities

500 that $\mathrm{CR}^{+}$cell densities, except RE medial (Fig. 5). The cell area densities found with the DAB staining of

$501 \mathrm{CR}^{+}$and $\mathrm{CB}^{+}$was almost identical to that of our immunofluorescence reactions (see above and Table S2), 
502 and the topographies were the same. Figure 5C summarizes our findings by atlas subregion showing that

$503 \mathrm{CB}^{+}$cell densities were consistently higher than $\mathrm{CR}^{+}$cell densities, with the exception of cells at RE

504 medial (REm) division. The same was true of RE caudoposterial (REcp) division, but only at mediocaudal

505 levels. Notably, in rostromedial (reuniens lateral-REl and reuniens ventral division-REv) and caudal levels

506 (reuniens caudal dorsal division-REcd) $\mathrm{CB}^{+}$cell densities were about twice the density of $\mathrm{CR}^{+}$cells (with

507 the exception of REm). We calculated the overall effect size across all RE subregions and levels and

508 found a modest effect of $\mathrm{CB}^{+}$density (Hedge's $\mathrm{d}=.32$ ).

509 Dual-site mPFC-HC projecting RE neurons are not $\mathrm{CB}^{+}$or $\mathrm{CR}^{+}$

A noteworthy feature of the midline thalamus is the presence of cells with monosynaptic

511 projections to both mPFC and HC (Hoover \& Vertes, 2012; Varela et al., 2014) which are thought to

512 contribute to rhythmic synchrony and communication in the mPFC-HC memory system (M. J. Dolleman-

513 van der Weel et al., 2019). Thus, we performed additional experiments to examine the calcium binding

514 protein expression in dual mPFC-HC projecting cells in RE. To do this, we injected two AAV retrograde

515 viral vectors in mPFC (prelimbic and infralimbic cortex; rAAV-CAG-tdTomato) and HC (ventral CA1; rAAV-

516 CAG-GFP) and then imaged the resultant tdTomato (red) and GFP (green) expression in RE (Fig. 6A) ( $\mathrm{n}$

$517=4$ rats). Coronal sections were counterstained with DAB to label CR $(n=2)$ and CB $(n=2)$ (see Figure

518 S1). We found cells in RE that were dual-labeled (Fig. 6B, yellow) that clustered predominantly in

519 consistent dorsal and ventral locations near the midline (Fig. 6B, cyan squares). Dual mPFC-HC

520 projecting cells represented only a small proportion of RE cells in the area (Fig. 6C) consistent with

521 previous reports (Hoover \& Vertes, 2012; Varela et al., 2014). Next, we looked at whether $\mathrm{CR}^{+}$or $\mathrm{CB}^{+}$

522 cells co-localized with dual mPFC-HC projecting cells in RE. Surprisingly, no $\mathrm{CR}^{+}$and $\mathrm{CB}^{+}$cells

523 overlapped RE dual-projecting cells. We also noticed (as before in Figs. 2-4C) that there were $\mathrm{CR}^{+}$and

$524 \mathrm{CB}^{+}$sparse areas, and interestingly these appeared to contain dual mPFC-HC projecting cells. To

525 examine this visual impression quantitatively, we measured the distance from a sample of RE dual-

526 projecting cells $(n=49)$ to every $C R^{+}$and $C B^{+}$cell within a 100 -micron radius $\left(D_{i i}-E_{i i}\right)$. There were very few

$527 \mathrm{CR}^{+}$and $\mathrm{CB}^{+}$cells nearby RE dual-projecting cells, and this count progressively increased with distance 
528 (Fig. 6F $\left.\mathrm{F}_{\mathrm{ii}}-\mathrm{G}_{\mathrm{ii}}\right)$. To confirm this relationship, we ran a linear regression between the cell counts by distance.

529 We found that $\mathrm{CR}^{+}$cell and $\mathrm{CB}^{+}$cell counts both increased significantly as a function of distance from

530 dual mPFC-HC projecting cells in RE (dorsal clusters: $\mathrm{CR}^{+}$cells $r=.57, r^{2}=.328 ; \mathrm{CB}^{+} r=.80 r^{2}=.646$;

531 ventral clusters: $\mathrm{CR}^{+}$cells $r=.84, r^{2}=.706 ; \mathrm{CB}^{+} r=.84, r^{2}=.888$; all $p$ 's $\left.<0.01\right)$. Overall, these findings

532 show that dual mPFC-HC projecting cells in RE are a neurobiologically unique cell type in that they lack

533 CR and CB (and PV) expression, and that their local cytoarchitecture clusters them within $\mathrm{CB}^{+}$and $\mathrm{CR}^{+}$

534 cell nests that occurred in multiple topographic locations within RE.

\section{DISCUSSION}

\section{Summary of Main Findings}

The present study examined the calcium binding protein (PV, CR and $C B$ ) organization of the

midline thalamus focusing on PVT, PT, RH and RE using a dual-labeling immunofluorescence approach.

We further targeted specific dual mPFC-RE projecting cells in RE using a dual retrograde AAV tracing

541 technique because these cells are theoretically critical to synchronous mPFC and HC activity (Dolleman-

542 van der Weel et al., 2019; Hoover \& Vertes, 2012; Varela et al., 2014). First, we did not find any PV ${ }^{+}$cells

543 in any of the nuclei of the midline thalamus, consistent with previous reports (Celio, 1990; Arai et al.,

544 1994; Bokor et al., 2002). However, we did find an abundance of $\mathrm{PV}^{+}$fibers in midline thalamus which are

545 known to be inhibitory afferents from TRN (Albéri et al., 2013; Arai et al., 1994; McKenna \& Vertes, 2004).

546 Next, we demonstrated that $\mathrm{CR}^{+}$and $\mathrm{CB}^{+}$labeling organized the midline thalamus into distinct cell-type

547 dominant zones. Notably, the dorsal and ventral $\mathrm{CR}^{+}$and $\mathrm{CB}^{+}$patterns mirrored each other suggesting a

548 common developmental trajectory of $\mathrm{CR}^{+}$and $\mathrm{CB}^{+}$cell densities throughout the midline thalamus

549 (Frassoni et al., 1998) in a pattern that simply flipped around the curvature of the rostral thalamus and 3V

550 (e.g., vertically flipping Fig. 2C aligns the cell distributions of RE exceptionally well with those in Fig. 2B).

551 That is, the dorsal midline thalamus (PVT and PT) contained a high density of $\mathrm{CR}^{+}$cells and fibers that

552 resembled a "T" or "Y" bordering the walls of the dorsal $3 \mathrm{~V}$ and populating the midline. Whereas, $\mathrm{CB}^{+}$

553 cells were populated ventrolaterally and dense in PT. The ventral midline thalamus (RH and RE) 
554 contained a high density of $\mathrm{CR}^{+}$cells resembling an inverted " $\mathrm{T}$ " or " $\mathrm{Y}$ " bordering the walls of the ventral

$5553 \mathrm{~V}$ and occupied the midline including the center of rostral $\mathrm{RH}$. $\mathrm{CB}^{+}$cells in ventral midline thalamus were

556 situated dorsolaterally and in lateral and caudal $\mathrm{RH}$. Throughout the midline thalamus, dual-labeled

$557 \mathrm{CR}^{+} / \mathrm{CB}^{+}$cells were contained in partially overlapping single-labeled $\mathrm{CR}^{+}$and $\mathrm{CB}^{+}$zones. We detailed

558 subregional variations on these patterns throughout the results, noting RE had the most complexity

559 (summarized in Fig. 7). While we found a consistently opposing pattern of CR and CB cell density in PVT

560 and RE across the rostro-caudal axis of the thalamus, with $\mathrm{CR}^{+}$cell density higher in $\mathrm{PVT}$ and $\mathrm{CB}^{+}$cell

561 density was higher in RE, these differences may be, in part, due to the lack of an atlas separation for the

$562 \mathrm{CB}^{+}$cell population in the dorsolateral areas of RE in the way that PT is separated from PVT. Lastly, we

563 showed that dual mPFC-HC projecting cells labeled with neither CR or CB, but were surrounded by rings

564 of cells expressing both calcium binding proteins (composed of $\mathrm{CR}^{+}, \mathrm{CB}^{+}$, and $\mathrm{CR}^{+} / \mathrm{CB}^{+}$cells). These dual

565 mPFC-HC projecting center-ring organizations are potentially important microcircuits for midline thalamic

566 integration and mPFC-HC synchronization.

\section{Calcium Binding Protein Distributions in Midline Thalamus}

568 Overall, our results are in strong agreement with the outcomes of other studies that looked at the 569 distribution of the calcium binding proteins in the rat thalamus that indicated that the midline thalamus is 570 particularly rich/dense with $\mathrm{CR}^{+}$and $\mathrm{CB}^{+}$cells (Arai et al., 1994; Bokor et al., 2002; Winsky et al., 1992).

571 However, we detail a few important differences with respect to the findings described in Arai et al. (1994),

572 who productively used a single-labeling chromagen approach, on the distribution of the $\mathrm{CR}^{+}$and $\mathrm{CB}^{+}$cells 573 in PVT, RH, and RE (our PT findings were nearly identical). First, Arai et al. (1994) indicated PVT was 574 mainly a CR-containing structure while we found both $\mathrm{CB}^{+}$and dual-labeled $\mathrm{CR}^{+} / \mathrm{CB}^{+}$cells common 575 throughout the region. PVT CR-labeling intensity and cells sizes were notably greater than for CB in PVT. 576 Second, Arai et al., (1994) showed RH was mostly a CR-containing structure, but our data demonstrates 577 that this is only true at the most rostromedial levels of $\mathrm{RH}$. In stark contrast, we found that $\mathrm{CB}^{+}$cells were 578 almost exclusively populated at lateral and caudal levels of $\mathrm{RH}$. Third, with respect to RE, Arai et al. 579 (1994) described this nucleus as containing similar densities of CR and CB, while we demonstrate that 
$580 \mathrm{RE}$ contained more $\mathrm{CB}^{+}$than $\mathrm{CR}^{+}$cells and exhibits several distinct $\mathrm{CR}^{+}, \mathrm{CB}^{+}$and $\mathrm{CR}^{+} / \mathrm{CB}^{+}$cell zones

581 (see Fig. 7 for details). The differences we found are likely due to the fact that we used a dual-labeling 582 immunofluorescence protocol that was (1) more able to pick up on detailed distributions of $\mathrm{CR}^{+}$and $\mathrm{CB}^{+}$ 583 labeling in direct relationship to each other, and (2) confirm the identity of dual-labeled $\mathrm{CR}^{+} / \mathrm{CB}^{+}$cells with 584 a confocal z-stack analysis.

585 Functional Implication of $\mathrm{CR}^{+}$and $\mathrm{CB}^{+}$Topographies in Midline Thalamus

It well known that calcium binding proteins such as $\mathrm{CR}^{+}$and $\mathrm{CB}^{+}$are crucially involved in neuronal

functions. While CR and CB have been chiefly classified as slow buffers, recent work suggest they can

also act as calcium sensors (Nelson \& Chazin, 1998; Schwaller, 2014) Generally, calcium binding proteins have been used as an important tool in differentiating various cell types in the brain (Andressen et al., 1993; Arai et al., 1994; DeFelipe, 1997; Gulyás et al., 1996; Jones \& Hendry, 1989). In fact, an early

591 classification of the thalamus separated cells based on their calcium binding protein expression (Jones, 592 1998; Jones, 2001). Of these, $\mathrm{CB}^{+}$cells in midline thalamus were classified as 'matrix' cells because of 593 their dedicated projections to multimodal sensory regions in superficial layers of the cortex; and $\mathrm{PV}^{+}$cells 594 were considered 'core' cells for their projections to areas involved in the processing of sensory or motor 595 information in middle cortical layers. While we did not find any $\mathrm{PV}^{+}$cells in midline thalamus, $\mathrm{CB}^{+}$cells 596 were abundant especially in PT, RH and dorsolateral RE. The midline thalamus might be considered 597 composed entirely of matrix cells involved in the processing of information from multiple brain regions in 598 much the same way promoting cortico-thalamo-cortico synchronization, although the value of this 599 distinction is not clear for further understanding subregional microcircuits in the midline thalamus without 600 further investigation (Dolleman-van der Weel et al., 2019). While a role of CR is less known at this level of 601 analysis, a population of $\mathrm{CR}^{+} \mathrm{RE}$ cells that project to entorhinal cortex has been described (Wouterlood et 602 al., 2007). We assume this is reflected in our observation of very dense and prominent $\mathrm{CR}^{+}$fibers that 603 extended throughout the shallow layers of entorhinal cortex but did not extend into perirhinal cortex, or 604 into other cortices, which appeared to have more $\mathrm{CB}^{+}$labeling. Given these entorhinal projections, $\mathrm{CR}^{+}$ 605 cells in midline thalamus also seem to target multimodal sensory regions of cortex like $\mathrm{CB}^{+}$cells. This 
suggest that the existence of separate and unique CR and CB zones in midline thalamus represent separate thalamo-cortical circuits.

Distinct $\mathrm{CR}^{+}, \mathrm{CB}^{+}$and $\mathrm{CR}^{+} / \mathrm{CB}^{+}$topographical zones in midline thalamus are likely associated with distinct rhythmicity like delta (e.g., Roy et al., 2017; Ferraris et al., 2018; Todorova and Zugaro, 2019; Schultheiss et al., 2020), theta (Hallock et al., 2016; Hasselmo et al., 2002; Jankowski et al., 2014; Lara-

611 Vásquez et al., 2016; Roy et al., 2017; Vertes et al., 2004), or with sharp-wave ripples (Jadhav et al., 2012; Jadhav et al., 2016). Good support for this notion stems from the demonstration that $\mathrm{CR}^{+}$cells in midline thalamus exhibit distinct in vivo electrophysiological profiles (Lara-Vásquez et al., 2016).

614 Specifically, Lara-Vasquez et al. (2016) found that $\mathrm{CR}^{+}$cells were more prone to bursting, not recruited in $615 \mathrm{HC}$ theta states, and inhibited by sharp-wave ripples. They also found that $\mathrm{CR}^{-}$neurons were less prone to bursting and had no apparent relationship to theta (regardless of labeling for CB). These cells were sampled from across the dorsal-ventral extent of the midline thalamus signifying a primal role for calcium binding protein status. Combined with the present results, this suggests special considerations should be given when recording from midline thalamic neurons as to their calcium binding protein identity. For example, activity recorded from the CR-rich zones in RE located along the midline or near the third ventricle will likely differ significantly from RE activity recorded from the CB-rich dorsolateral areas, 622 particularly with respect to their rhythmic and bursting profiles.

\section{Dual mPFC-HC projecting RE cells are distinct from $\mathrm{CR}^{+}$and $\mathrm{CB}^{+}$cell populations}

Using a retrograde AAV viral approach we observed distinct and stereotyped clusters of RE cells with monosynaptic projections both to mPFC (prelimbic and infralimbic area) and ventral CA1. This finding

626 is in agreement with two other studies that used more traditional tracing techniques (Hoover \& Vertes, 627 2012; Varela et al., 2014). Specifically, Hoover and Vertes (2012) found several clusters of dual labeled 628 cells in RE following injections of the retrograde tracers fluorogold and fluororuby in mPFC (PL/IL) and dorsal CA1, and in vCA1 and subiculum. Hoover and Vertes (2012) suggested that the functional roles of

630 these cells were to support limbic subcortical and cortical interactions and/or the convergence and 631 integration among other limbic-related structures. Varela et al. (2014) also demonstrated the existence of 
632 dual mPFC-HC projecting cells in RE following injections of cholera toxin (CTB) tracers. Varela et al.

633 (2014) speculated these cells may be critical for the synchronization of target regions during exploration,

634 transfer of mnemonic information between mPFC-HC, and modulation of certain phases of cortical spindle

635 oscillations. It's notable that we found that the dual projecting cells lacked CR or CB, but were surrounded

636 by a ring of $\mathrm{CR}^{+}, \mathrm{CB}^{+}$and $\mathrm{CR}^{+} / \mathrm{CB}^{+}$cells. That is, we observed $\mathrm{CB}^{+}, \mathrm{CR}^{+}$and $\mathrm{CR}^{+} / \mathrm{CB}^{+}$cells formed well-

637 defined circular clusters in regions that were sparse or seemly absent of $\mathrm{CR}^{+}$or $\mathrm{CB}^{+}$cells (within a $100 \mu \mathrm{m}$

638 radius). Reliably, $\mathrm{CR}$ and $\mathrm{CB}$ cell densities were scant near dual mPFC-HC projecting cells, but cell

639 densities rapidly increased with distance. Speculatively, this organization may provide a microcircuit

640 means for integrating input activity from several different cell types and then synchronizing outputs to

$641 \mathrm{mPFC}$ and CA1 for triggering coordinated rhythmic modes (e.g., delta or theta). Interrogating these cells

642 further will require sophisticated functional approaches such as optogenetics delivered with combinatorial

643 retrograde and Cre-dependent viral constructs.

\section{Conclusion}

Most often, neurons in midline thalamus are assumed to be a relatively homogeneous group of 646 excitatory (glutamatergic) projection neurons (Bokor et al., 2002), but here we detailed several distinct 647 zones in the midline thalamus based on the expression of $\mathrm{CR}$ and $\mathrm{CB}$, or lack thereof in dual mPFC-HC 648 projecting cells. While experiments have productively targeted entire regions of the midline thalamus, 649 most commonly RH/RE with inactivations or lesions (Cholvin et al., 2013; Hallock et al., 2013; Hembrook 650 et al., 2012; Layfield et al., 2015; Loureiro et al., 2012), we suggest it may be more productive for future 651 experiments to separately target $\mathrm{CR}^{+}, \mathrm{CB}^{+}$, and dual mPFC-HC projecting cells to better understand the 652 computational and/or rhythmic contributions of the midline thalamus to the mPFC-HC system. 

REFERENCES

656 Ahn, J. H., Hong, S., Park, J. H., Kim, I. H., Cho, J. H., Lee, T.-K., Lee, J.-C., Chen, B. H., Shin, B.-N., Bae, E. J., Jeon, Y. H., Kim, Y.-M., Won, M.-H., \& Choi, S. Y. (2017). Immunoreactivities of calbindinD28k, calretinin and parvalbumin in the somatosensory cortex of rodents during normal aging. Molecular Medicine Reports, 16(5), 7191-7198. https://doi.org/10.3892/mmr.2017.7573

Aika, Y., Ren, J. Q., Kosaka, K., \& Kosaka, T. (1994). Quantitative analysis of GABA-like-immunoreactive and parvalbumin-containing neurons in the CA1 region of the rat hippocampus using a stereological method, the disector. Experimental Brain Research, 99(2). https://doi.org/10.1007/BF00239593

Al-Mashhadi, S., Simpson, J. E., Heath, P. R., Dickman, M., Forster, G., Matthews, F. E., Brayne, C., Ince, P. G., Wharton, S. B., \& Medical Research Council Cognitive Function and Ageing Study. (2015). Oxidative glial cell damage associated with white matter lession in the aging human brain:

Albéri, L., Lintas, A., Kretz, R., Schwaller, B., \& Villa, A. E. P. (2013). The calcium-binding protein parvalbumin modulates the firing 1 properties of the reticular thalamic nucleus bursting neurons. Journal of Neurophysiology, 109(11), 2827-2841. https://doi.org/10.1152/jn.00375.2012

Andressen, C., Blümcke, I., \& Celio, M. R. (1993). Calcium-binding proteins: Selective markers of nerve

Arai, R., Jacobowitz, D. M., \& Deura, S. (1994). Distribution of calretinin, calbindin-D28k, and parvalbumin in the rat thalamus. Brain Research Bulletin, 33(5), 595-614. https://doi.org/10.1016/03619230(94)90086-8 cells. Cell and Tissue Research, 271(2), 181-208. https://doi.org/10.1007/BF00318606

Anaconda Software Distribution. (2016). Anaconda (Version 2-2.4.0). [Computer software]. Retrieved from: https://anaconda.com

Barker, G. R. I., \& Warburton, E. C. (2018). A critical role for the nucleus reuniens in long-rerm, but not short-term associative recognition memory formation. The Journal of Neuroscience, 38(13), 32083217. https://doi.org/10.1523/JNEUROSCI.1802-17.2017 
681 Bokor, H., Csáki, Á., Kocsis, K., \& Kiss, J. (2002). Cellular architecture of the nucleus reuniens thalami and its putative aspartatergic/glutamatergic projection to the hippocampus and medial septum in the

Braak, H., \& Braak, E. (1991). Alzheimer's disease affects limbic nuclei of the thalamus. Acta Neuropathologica, 81(3), 261-268. https://doi.org/10.1007/BF00305867

Burwell, R. D. (2000). The parahippocampal region: Corticocortical connectivity. Annals of the New York Academy of Sciences, 911, 25-42. https://doi.org/10.1111/j.1749-6632.2000.tb06717.x

Cassel, J.-C., de Vasconcelos, A., Loureiro, M., Cholvin, T., Dalrymple-Alford, J. C., \& Vertes, R. P. behavioral implications. Progress in Neurobiology, 111, 34-52.

Celio, M. R. (1990). Calbindin D-28k and parvalbumin in the rat nervous system. Neuroscience, 35(2), 375-475. https://doi.org/10.1016/0306-4522(90)90091-H

Cenquizca, L. A., \& Swanson, L. W. (2007). Spatial organization of direct hippocampal field CA1 axonal projections to the rest of the cerebral cortex. Brain Research Reviews, 56(1), 1-26. https://doi.org/10.1016/j.brainresrev.2007.05.002

Choi, E. A., \& McNally, G. P. (2017). Paraventricular thalamus balances danger and reward. The Journal of Neuroscience, 37(11), 3018-3029. https://doi.org/10.1523/JNEUROSCI.3320-16.2017

Cholvin, T., Loureiro, M., Cassel, R., Cosquer, B., Geiger, K., De Sa Nogueira, D., Raingard, H., Robelin, L., Kelche, C., de Vasconcelos, A., \& Cassel, J.-C. (2013). The Ventral Midline Thalamus Contributes to Strategy Shifting in a Memory Task Requiring Both Prefrontal Cortical and Hippocampal Functions. Journal of Neuroscience, 33(20), 8772-8783. https://doi.org/10.1523/JNEUROSCI.0771-13.2013

Churchwell, J. C., \& Kesner, R. P. (2011). Hippocampal-prefrontal dynamics in spatial working memory: Interactions and independent parallel processing. Behavioural Brain Research, 225(2), 389-395. 
https://doi.org/10.1016/j.bbr.2011.07.045

Condé, F., Lund, J. S., Jacobowitz, D. M., Baimbridge, K. G., \& Lewis, D. A. (1994). Local circuit neurons immunoreactive for calretinin, calbindin D-28k or parvalbumin in monkey prefronatal cortex: Distribution and morphology: CALCIUM-BINDING PROTEINS IN MONKEY PREFRONTAL CORTEX. Journal of Comparative Neurology, 341(1), 95-116.

https://doi.org/10.1002/cne.903410109

Csillik, B., Mihály, A., Krisztin-Péva, B., Chadaide, Z., Samsam, M., Knyihár-Csillik, E., \& Fenyo, R. (2005). GABAergic parvalbumin-immunoreactive large calyciform presynaptic complexes in the reticular nucleus of the rat thalamus. Journal of Chemical Neuroanatomy, 30(1), 17-26. https://doi.org/10.1016/j.jchemneu.2005.03.010

DeFelipe, J. (1997). Types of neurons, synaptic connections and chemical characteristics of cells immunoreactive for calbindin-D28K, parvalbumin and calretinin in the neocortex. Journal of Chemical Neuroanatomy, 14(1), 1-19. https://doi.org/10.1016/S0891-0618(97)10013-8

del Río, M. R., \& DeFelipe, J. (1996). Colocalization of calbindin D-28k, calretinin, and GABA immunoreactivities in neurons of the human temporal cortex. Journal of Comparative Neurology, 369(3), 472-482. https://doi.org/10.1002/(SICI)1096-9861(19960603)369:3<472::AIDCNE11>3.0.CO;2-K

Dolleman-van der Weel, M. J., Griffin, A. L., Ito, H. T., Shapiro, M. L., Witter, M. P., Vertes, R. P., \& Allen, T. A. (2019). The nucleus reuniens of the thalamus sits at the nexus of a hippocampus and medial prefrontal cortex circuit enabling memory and behavior. Learning \& Memory, 26(7), 191-205. https://doi.org/10.1101//m.048389.118

Dolleman-van der Weel, M., \& Witter, M. P. (1996). Projections from the nucleus reuniens thalami to the entorhinal cortex, hippocampal field CA1, and the subiculum in the rat arise from different populations of neurons. Journal of Comparative Neurology, 364(4), 637-650. https://doi.org/10.1002/(sici)1096-9861(19960122)364:4<637::aid-cne3>3.0.co;2-4

Eichenbaum, H. (2017). Prefrontal-hippocampal interactions in episodic memory. Nature Reviews 
Neuroscience, 18(9), 547-558. https://doi.org/10.1038/nrn.2017.74

734 Ferino, F., Thierry, A. M., \& Glowinski, J. (1987). Anatomical and electrophysiological evidence for a direct projection from ammon's horn to the medial prefrontal cortex in the rat. Experimental Brain Research, 65(2). https://doi.org/10.1007/BF00236315

Ferraris, M., Ghestem, A., Vicente, A. F., Nallet-Khosrofian, L., Bernard, C., \& Quilichini, P. P. (2018). The nucleus reuniens controls long-range hippocampo-prefrontal gamma synchronization during slow oscillations. The Journal of Neuroscience, 38(12), 3026-3038. https://doi.org/10.1523/JNEUROSCI.3058-17.2018

Fonseca, M., \& Soriano, E. (1995). Calretinin-immunoreactive neurons in the normal human temporal cortex and in Alzheimer's disease. Brain Research, 691(1-2), 83-91. https://doi.org/10.1016/00068993(95)00622-W

Frassoni, C., Arcelli, P., Selvaggio, M., \& Spreafico, R. (1998). Calretinin immunoreactivity in the developing thalamus of the rat: A marker of early generated thalamic cells. Neuroscience, 83(4), 1203-1214. https://doi.org/10.1016/S0306-4522(97)00443-0

Fuchs, E. C., Zivkovic, A. R., Cunningham, M. O., Middleton, S., LeBeau, F. E. N., Bannerman, D. M., Rozov, A., Whittington, M. A., Traub, R. D., Rawlins, J. N. P., \& Monyer, H. (2007). Recruitment of

Furtak, S. C., Wei, S.-M., Agster, K. L., \& Burwell, R. D. (2007). Functional neuroanatomy of the Parvalbumin-Positive Interneurons Determines Hippocampal Function and Associated Behavior. Neuron, 53(4), 591-604. https://doi.org/10.1016/j.neuron.2007.01.031

Fuster, J. M. (1995). Cognitive Support of Behavior. Plasticity in the central nervous system: learning and memory, 149.

Gelinas, J. N., Khodagholy, D., Thesen, T., Devinsky, O., \& Buzsáki, G. (2016). Interictal epileptiform 
Gulyás, A. I., Hájos, N., \& Freund, T. F. (1996). Interneurons Containing Calretinin Are Specialized to Control Other Interneurons in the Rat Hippocampus. The Journal of Neuroscience, 16(10), 33973411. https://doi.org/10.1523/JNEUROSCI.16-10-03397.1996

Hallock, H L, Wang, A., \& Griffin, A. L. (2016). Ventral Midline Thalamus Is Critical for HippocampalPrefrontal Synchrony and Spatial Working Memory. Journal of Neuroscience, 36(32), 8372-8389. https://doi.org/10.1523/JNEUROSCI.0991-16.2016

Hallock, Henry L, Wang, A., Shaw, C. L., \& Griffin, A. L. (2013). Transient inactivation of the thalamic nucleus reuniens and rhomboid nucleus produces deficits of a working-memory dependent tactilevisual conditional discrimination task. Behavioral Neuroscience, 127(6), 860-866. https://doi.org/10.1037/a0034653

Hasselmo, M. E., Bodelón, C., \& Wyble, B. P. (2002). A proposed function for hippocampal theta rhythm: Separate phases of encoding and retrieval enhance reversal of prior learning. Neural Computation, 14(4), 793-817. https://doi.org/10.1162/089976602317318965

Hauer, B. E., Pagliardini, S., \& Dickson, C. T. (2019). The Reuniens Nucleus of the Thalamus Has an Essential Role in Coordinating Slow-Wave Activity between Neocortex and Hippocampus. Eneuro, 6(5), ENEURO.0365--19.2019. https://doi.org/10.1523/ENEURO.0365-19.2019

Hembrook, J. R., Onos, K. D., \& Mair, R. G. (2012). Inactivation of ventral midline thalamus produces selective spatial delayed conditional discrimination impairment in the rat. Hippocampus, 22(4), 853860. https://doi.org/10.1002/hipo.20945

Hof, P. R., Glezer, I. I., Condé, F., Flagg, R. A., Rubin, M. B., Nimchinsky, E. A., \& Vogt Weisenhorn, D. M. (1999). Cellular distribution of the calcium-binding proteins parvalbumin, calbindin, and calretinin in the neocortex of mammals: phylogenetic and developmental patterns. Journal of Chemical Neuroanatomy, 16(2), 77-116. https://doi.org/10.1016/S0891-0618(98)00065-9

Hoover, W. B., \& Vertes, R. P. (2012). Collateral projections from nucleus reuniens of thalamus to hippocampus and medial prefrontal cortex in the rat: A single and double retrograde fluorescent labeling study. Brain Structure and Function, 217(2), 191-209. https://doi.org/10.1007/s00429-011- 
785

786

0345-6

Hsu, D. T., Kirouac, G. J., Zubieta, J.-K., \& Bhatnagar, S. (2014). Contributions of the paraventricular thalamic nucleus in the regulation of stress, motivation, and mood. Frontiers in Behavioral Neuroscience, 8. https://doi.org/10.3389/fnbeh.2014.00073

Hunsaker, M. R., \& Kesner, R. P. (2018). Unfolding the cognitive map: The role of hippocampal and extrahippocampal substrates based on a systems analysis of spatial processing. Neurobiology of Learning and Memory, 147, 90-119. https://doi.org/10.1016/j.nlm.2017.11.012

Ito, H. T., Zhang, S.-J., Witter, M. P., Moser, E. I., \& Moser, M.-B. (2015). A prefrontal-thalamohippocampal circuit for goal-directed spatial navigation. Nature, 522(7554), 50-55. https://doi.org/10.1038/nature14396

Jadhav, S. P., Kemere, C., German, P. W., \& Frank, L. M. (2012). Awake hippocampal sharp-wave ripples support spatial memory. Science, 336(6087), 1454-1458. https://doi.org/10.1126/science.1217230

Jadhav, S. P. P., Rothschild, G., Roumis, D. K. K., \& Frank, L. M. M. (2016). Coordinated Excitation and Inhibition of Prefrontal Ensembles during Awake Hippocampal Sharp-Wave Ripple Events. Neuron, 90(1), 113-127. https://doi.org/10.1016/j.neuron.2016.02.010

Jankowski, M. M., Islam, M. N., Wright, N. F., Vann, S. D., Erichsen, J. T., Aggleton, J. P., \& O’Mara, S. M. (2014). Nucleus reuniens of the thalamus contains head direction cells. ELife, 3(July2014), 1-10. https://doi.org/10.7554/eLife.03075

Jayachandran, M., Linley, S. B., Schlecht, M., Mahler, S. V, Vertes, R. P., \& Allen, T. A. (2019). Prefrontal Pathways Provide Top-Down Control of Memory for Sequences of Events. Cell Reports, 28(3), 640-654.e6. https://doi.org/10.1016/j.celrep.2019.06.053

Jin, J., \& Maren, S. (2015). Prefrontal-hippocampal interactions in memory and emotion. Frontiers in Systems Neuroscience, 9. https://doi.org/10.3389/fnsys.2015.00170 Jones, E G. (1998). Viewpoint: the core and matrix of thalamic organization. Neuroscience, 85(2), 331345. https://doi.org/10.1016/S0306-4522(97)00581-2 
811 Jones, E G, \& Hendry, S. H. C. (1989). Differential calcium binding protein immunoreactivity distinguishes 812 classes of relay neurons in monkey thalamic nuclei. European Journal of Neuroscience, 1(3), 222246. https://doi.org/10.1111/j.1460-9568.1989.tb00791.x

814 Jones, Edward G. (2001). The thalamic matrix and thalamocortical synchrony. Trends in Neurosciences, 815 24(10), 595-601. https://doi.org/10.1016/S0166-2236(00)01922-6

816 Kawano, J. (2001). Suprachiasmatic nucleus projections to the paraventricular thalamic nucleus of the rat. Thalamus \& Related Systems, 1(3), 197-202. https://doi.org/10.1016/S1472-9288(01)00019-X

818 Kerr, K. M., Agster, K. L., Furtak, S. C., \& Burwell, R. D. (2007). Functional neuroanatomy of the parahippocampal region: The lateral and medial entorhinal areas. Hippocampus, 17(9), 697-708. https://doi.org/10.1002/hipo.20315

821 Kirichenko, E. Y., Matsionis, A. E., Povilaitite, P. E., Akimenko, M. A., \& Logvinov, A. K. (2017). and the Reticular Nucleus of the Thalamus in Rats (an immunohistochemical study). Neuroscience and Behavioral Physiology, 47(6), 621-626. https://doi.org/10.1007/s11055-017-0444-9

Kosaka, T., Wu, J.-Y., \& Benoit, R. (1988). GABAergic neurons containing somatostatin-like immunoreactivity in the rat hippocampus and dentate gyrus. Experimental Brain Research, 71(2). https://doi.org/10.1007/BF00247498

Lara-Vásquez, A., Espinosa, N., Durán, E., Stockle, M., \& Fuentealba, P. (2016). Midline thalamic

Layfield, D. M., Patel, M., Hallock, H., \& Griffin, A. L. (2015). Inactivation of the nucleus neurons are differentially engaged during hippocampus network oscillations. Scientific Reports, 6(1), reuniens/rhomboid causes a delay-dependent impairment of spatial working memory. Neurobiology

834 Li, S., \& Kirouac, G. J. (2008). Projections from the paraventricular nucleus of the thalamus to the 
837 Lisman, J. E., Pi, H. J., Zhang, Y., \& Otmakhova, N. A. (2010). A Thalamo-Hippocampal-Ventral

838 Tegmental Area Loop May Produce the Positive Feedback that Underlies the Psychotic Break in Schizophrenia. Biological Psychiatry, 68(1), 17-24. https://doi.org/10.1016/j.biopsych.2010.04.007

Loureiro, M., Cholvin, T., Lopez, J., Merienne, N., Latreche, A., Cosquer, B., Geiger, K., Kelche, C., Cassel, J.-C., \& de Vasconcelos, A. (2012). The Ventral Midline Thalamus (Reuniens and Rhomboid Nuclei) Contributes to the Persistence of Spatial Memory in Rats. Journal of Neuroscience, 32(29),

Majercikova, Z., Weering, H. van, Scsukova, S., Mikkelsen, J. D., \& Kiss, A. (2012). A new approach of light microscopic immunohistochemical triple-staining: combination of Fos labeling with diaminobenzidine-nickel and neuropeptides labeled with Alexa488 and Alexa555 fluorescent dyes. Endocrine Regulations, 46(04), 217-223. https://doi.org/10.4149/endo_2012_04_217

Matzeu, A., Zamora-Martinez, E. R., \& Martin-Fardon, R. (2014). The paraventricular nucleus of the thalamus is recruited by both natural rewards and drugs of abuse: recent evidence of a pivotal role for orexin/hypocretin signaling in this thalamic nucleus in drug-seeking behavior. Frontiers in

McGaugh, J. L., Bermudez-Rattoni, F., \& Prado-Alcala, R. A. (2019). Plasticity in the central nervous system: Learning and memory. In Plasticity in the Central Nervous System: Learning and Memory. https://doi.org/10.4324/9781315789279

McKenna, J. T., \& Vertes, R. P. (2004). Afferent projections to nucleus reuniens of the thalamus. Journal of Comparative Neurology, 480(2), 115-142. https://doi.org/10.1002/cne.20342

McQuin, C., Goodman, A., Chernyshev, V., Kamentsky, L., Cimini, B. A., Karhohs, K. W., Doan, M., Ding, L., Rafelski, S. M., Thirstrup, D., Wiegraebe, W., Singh, S., Becker, T., Caicedo, J. C., \& Carpenter, A. E. (2018). CellProfiler 3.0: Next-generation image processing for biology. PLOS Biology, 16(7), e2005970. https://doi.org/10.1371/journal.pbio.2005970 
proteins and gaba. Neuroscience, 48(1), 29-43. https://doi.org/10.1016/0306-4522(92)90335-Y

864

865

866

Moyer, J. R., Furtak, S. C., McGann, J. P., \& Brown, T. H. (2011). Aging-related changes in calciumbinding proteins in rat perirhinal cortex. Neurobiology of Aging, 32(9), 1693-1706. https://doi.org/10.1016/j.neurobiolaging.2009.10.001

Nelson, A. J. D., Hindley, E. L., Haddon, J. E., Vann, S. D., \& Aggleton, J. P. (2014). A novel role for the rat retrosplenial cortex in cognitive control. Learning \& Memory, 21(2), 90-97. https://doi.org/10.1101/lm.032136.113

Nelson, M. R., \& Chazin, W. J. (1998). Structures of EF-hand Ca2+-binding proteins: Diversity in the organization, packing and response to Ca2+ binding. BioMetals, 11(4), 297-318. https://doi.org/10.1023/A:1009253808876

Penzo, M. A., Robert, V., Tucciarone, J., De Bundel, D., Wang, M., Van Aelst, L., Darvas, M., Parada, L. F., Palmiter, R. D., He, M., Huang, Z. J., \& Li, B. (2015). The paraventricular thalamus controls a central amygdala fear circuit. Nature, 519(7544), 455-459. https://doi.org/10.1038/nature13978

Preston, A. R., \& Eichenbaum, H. (2013). Review Interplay of Hippocampus and Prefrontal Cortex in Memory. CURBIO, 23, R764--R773. https://doi.org/10.1016/j.cub.2013.05.041

Reynolds, G. P., Abdul-Monim, Z., Neill, J. C., \& Zhang, Z.-J. (2004). Calcium binding protein markers of GABA deficits in schizophrenia — post mortem studies and animal models. Neurotoxicity Research, 6(1), 57-61. https://doi.org/10.1007/BF03033297

Rogers, J. H., \& Résibois, A. (1992). Calretinin and calbindin-D28k in rat brain: Patterns of partial colocalization. Neuroscience, 51(4), 843-865. https://doi.org/10.1016/0306-4522(92)90525-7

Roy, A., Svensson, F. P., Mazeh, A., \& Kocsis, B. (2017). Prefrontal-hippocampal coupling by theta rhythm and by $2-5 \mathrm{~Hz}$ oscillation in the delta band: The role of the nucleus reuniens of the thalamus. Brain Structure and Function, 222(6), 2819-2830. https://doi.org/10.1007/s00429-017-1374-6

Schultheiss, N. W., Schlecht, M., Jayachandran, M., Brooks, D. R., McGlothan, J. L., Guilarte, T. R., \& Allen, T. A. (2020). Awake delta and theta-rhythmic hippocampal network modes during intermittent locomotor behaviors in the rat. Behavioral Neuroscience, undefined(undefined), undefined. 
https://doi.org/10.1037/bne0000409

Schwaller, B. (2014). Calretinin: from a "simple" Ca2+ buffer to a multifunctional protein implicated in many biological processes. Frontiers in Neuroanatomy, 8. https://doi.org/10.3389/fnana.2014.00003

Sherman, S. M. (2017). Functioning of Circuits Connecting Thalamus and Cortex. In R. Terjung (Ed.), Comprehensive Physiology (pp. 713-739). John Wiley \& Sons, Inc.

Schindelin, J., Arganda-Carreras, I., Frise, E., Kaynig, V., Longair, M., Pietzsch, T., Preibisch, S., Rueden,

Skelin, I., Kilianski, S., \& McNaughton, B. L. (2019). Hippocampal coupling with cortical and subcortical structures in the context of memory consolidation. Neurobiology of Learning and Memory, 160, 21-

Sloviter, R. S. (1989). Calcium-binding protein (calbindin-D28k) and parvalbumin immunocytochemistry:

$$
\text { Localization in the rat hippocampus with specific reference to the selective vulnerability of }
$$
hippocampal neurons to seizure activity. The Journal of Comparative Neurology, 280(2), 183-196. https://doi.org/10.1002/cne.902800203

Spellman, T., Rigotti, M., Ahmari, S. E., Fusi, S., Gogos, J. A., \& Gordon, J. A. (2015). Hippocampalprefrontal input supports spatial encoding in working memory. Nature, 522(7556), 309-314. https://doi.org/10.1038/nature14445

Su, H.-S., \& Bentivoglio, M. (1990). Thalamic midline cell populations projecting to the nucleus accumbens, amygdala, and hippocampus in the rat. The Journal of Comparative Neurology, 297(4), 582-593. https://doi.org/10.1002/cne.902970410

Swanson, L. W. (2018). Brain maps 4.0-Structure of the rat brain: An open access atlas with global nervous system nomenclature ontology and flatmaps. Journal of Comparative Neurology, 526(6), 935-943. https://doi.org/10.1002/cne.24381 
915 Todorova, R., \& Zugaro, M. (2019). Isolated cortical computations during delta waves support memory

916 consolidation. Science, 366(6463), 377-381. https://doi.org/10.1126/science.aay0616

917 Tollemar, V., Tudzarovski, N., Boberg, E., Törnqvist Andrén, A., Al-Adili, A., Le Blanc, K., Garming Legert,

918 K., Bottai, M., Warfvinge, G., \& Sugars, R. V. (2018). Quantitative chromogenic

919 immunohistochemical image analysis in cellprofiler software: Quantitative chromogenic

920 immunohistochemistry. Cytometry Part A, 93(10), 1051-1059. https://doi.org/10.1002/cyto.a.23575

921 Urbán, Z., Maglóczky, Z., \& Freund, T. F. (2002). Calretinin-containing interneurons innervate both

922 principal cells and interneurons in the CA1 region of the human hippocampus. Acta Biologica

923 Hungarica, 53(1-2), 205-220. https://doi.org/10.1556/ABiol.53.2002.1-2.19

924 Van Brederode, J. F. M., Helliesen, M. K., \& Hendrickson, A. E. (1991). Distribution of the calcium-binding proteins parvalbumin and calbindin-D28k in the sensorimotor cortex of the rat. Neuroscience, 44(1), 157-171. https://doi.org/10.1016/0306-4522(91)90258-P

927 Varela, C., Kumar, S., Yang, J. Y., \& Wilson, M. A. (2014). Anatomical substrates for direct interactions between hippocampus, medial prefrontal cortex, and the thalamic nucleus reuniens. Brain Structure and Function, 219(3), 911-929. https://doi.org/10.1007/s00429-013-0543-5

930 Vertes, R. P., \& Hoover, W. B. (2008). Projections of the paraventricular and paratenial nuclei of the 931 dorsal midline thalamus in the rat. The Journal of Comparative Neurology, 508(2), 212-237. 932 https://doi.org/10.1002/cne.21679

933 Vertes, R. P., Hoover, W. B., Do Valle, A. C., Sherman, A., \& Rodriguez, J. J. (2006). Efferent projections 934 of reuniens and rhomboid nuclei of the thalamus in the rat. Journal of Comparative Neurology, 935 499(5). https://doi.org/10.1002/cne.21135

936 Vertes, R. P., Hoover, W. B., Szigeti-Buck, K., \& Leranth, C. (2007). Nucleus reuniens of the midline 937 thalamus: Link between the medial prefrontal cortex and the hippocampus. Brain Research Bulletin, 938 71(6). https://doi.org/10.1016/j.brainresbull.2006.12.002

939 Vertes, R. P., Hoover, W. B., \& Viana Di Prisco, G. (2004). Theta rhythm of the hippocampus: subcortical control and functional significance. In Behavioral and cognitive neuroscience reviews (Vol. 3, Issue 
3, pp. 173-200). Behav Cogn Neurosci Rev. https://doi.org/10.1177/1534582304273594

942 Vertes, R. P., Linley, S. B., \& Hoover, W. B. (2015). Limbic circuitry of the midline thalamus. In

$943 \quad$ Neuroscience and Biobehavioral Reviews (Vol. 54). https://doi.org/10.1016/j.neubiorev.2015.01.014

944 Viena, T. D., Linley, S. B., \& Vertes, R. P. (2018). Inactivation of nucleus reuniens impairs spatial working 945 memory and behavioral flexibility in the rat. Hippocampus, 28(4). https://doi.org/10.1002/hipo.22831

946 Winsky, L., Montpied, P., Arai, R., Martin, B. M., \& Jacobowitz, D. M. (1992). Calretinin distribution in the 947 thalamus of the rat: Immunohistochemical and in situ hybridization histochemical analyses.

Witter, M. P., Doan, T. P., Jacobsen, B., Nilssen, E. S., \& Ohara, S. (2017). Architecture of the Entorhinal Cortex A Review of Entorhinal Anatomy in Rodents with Some Comparative Notes. Frontiers in Systems Neuroscience, 11, 46. https://doi.org/10.3389/fnsys.2017.00046

Wouterlood, F. G., Canto, C. B., Aliane, V., Boekel, A. J., Grosche, J., Härtig, W., Beliën, J. A. M., \& decarboxylase and calretinin in rat entorhinal cortex. Brain Structure and Function, 212(3-4), 303319. https://doi.org/10.1007/s00429-007-0163-z

Wouterlood, F. G., Grosche, J., \& Härtig, W. (2001). Co-localization of calretinin and calbindin in distinct cells in the hippocampal formation of the rat. Brain Research, 922(2), 310-314. https://doi.org/10.1016/S0006-8993(01)03220-6

Xu, W., \& Sudhof, T. C. (2013). A Neural Circuit for Memory Specificity and Generalization. Science, 339(6125), 1290-1295. https://doi.org/10.1126/science.1229534

Young, J. K., Wu, M., Manaye, K. F., Kc, P., Allard, J. S., Mack, S. O., \& Haxhiu, M. A. (2005). Orexin

Zimmer, D. B., Cornwall, E. H., Landar, A., \& Song, W. (1995). The S100 protein family: History, function, and expression. Brain Research Bulletin, 37(4), 417-429. https://doi.org/10.1016/0361- 
bioRxiv preprint doi: https://doi.org/10.1101/2020.07.21.214973; this version posted July 21, 2020. The copyright holder for this preprint (which was not certified by peer review) is the author/funder, who has granted bioRxiv a license to display the preprint in perpetuity. It is made available under aCC-BY-NC-ND 4.0 International license. 

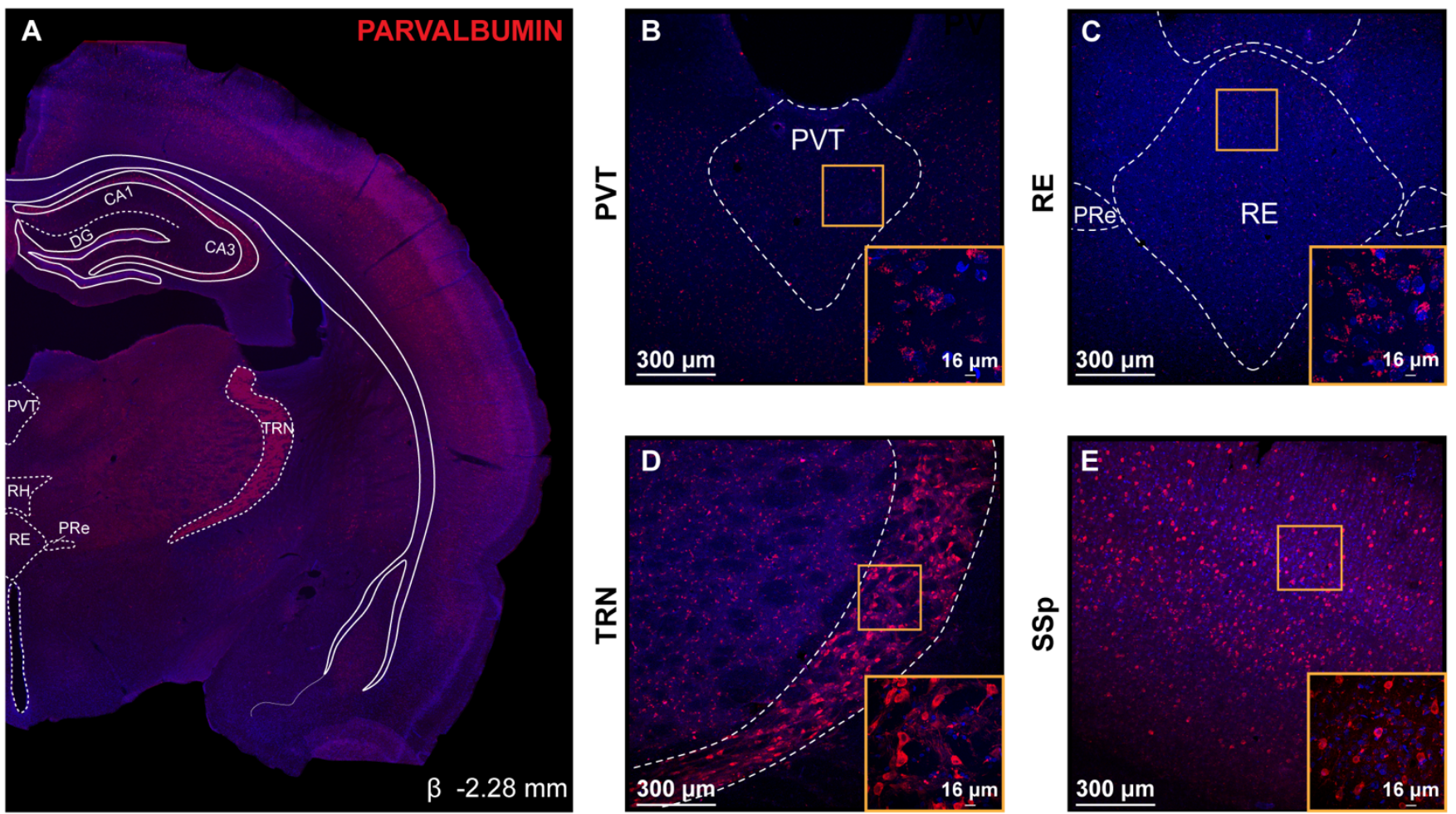

Figure 1. Absence of parvalbumin $\left(\mathrm{PV}^{+}\right)$cell bodies in midline thalamus

A: Representative coronal section $(\beta-2.28 \mathrm{~mm})$ showing $\mathrm{PV}^{+}$cell body expression throughout several regions of the brain. $\mathrm{PV}^{+}$expression shown in red and DAPI in blue. Overlay shown adapted from Swanson (2018) to highlight thalamic structures.

B-E: Confocal images showing PV immunoreactivity in PVT (B), RE (C), TRN (D) and SSp (E). Neither PVT nor RE contain $\mathrm{PV}^{+}$cell bodies, however $\mathrm{PV}$ immunoreacted puncta was abundant near or between their cell bodies (B-C insets). Scale bar $=300 \mu \mathrm{m}$. Inset scale bar $=16 \mu \mathrm{m}$.

D: $\mathrm{PV}^{+}$cell bodies with a characteristic large immunonegative nuclei were seen in TRN (D inset).

E: $\mathrm{PV}^{+}$cell bodies were also observed in SSp cortex showing their distinct sparse but organized layer distribution (E inset). Gold squares represent regions of $60 \mathrm{X}$ magnification shown in inset.

Abbreviations: $\beta$, bregma; CA1, CA1 subfield of the hippocampus; CA3, CA3 subfield of the hippocampus; DAPI, 4',6-Diamidino-2-phenylindole dihydrochloride; DG, dentate gyrus; PV, parvalbumin; PVT, paraventricular; PRe, perireuniens; RE, nucleus reuniens; $\mathrm{RH}$, rhomboid; SSp, primary somatosensory cortex; TRN, thalamic reticular nucleus. 

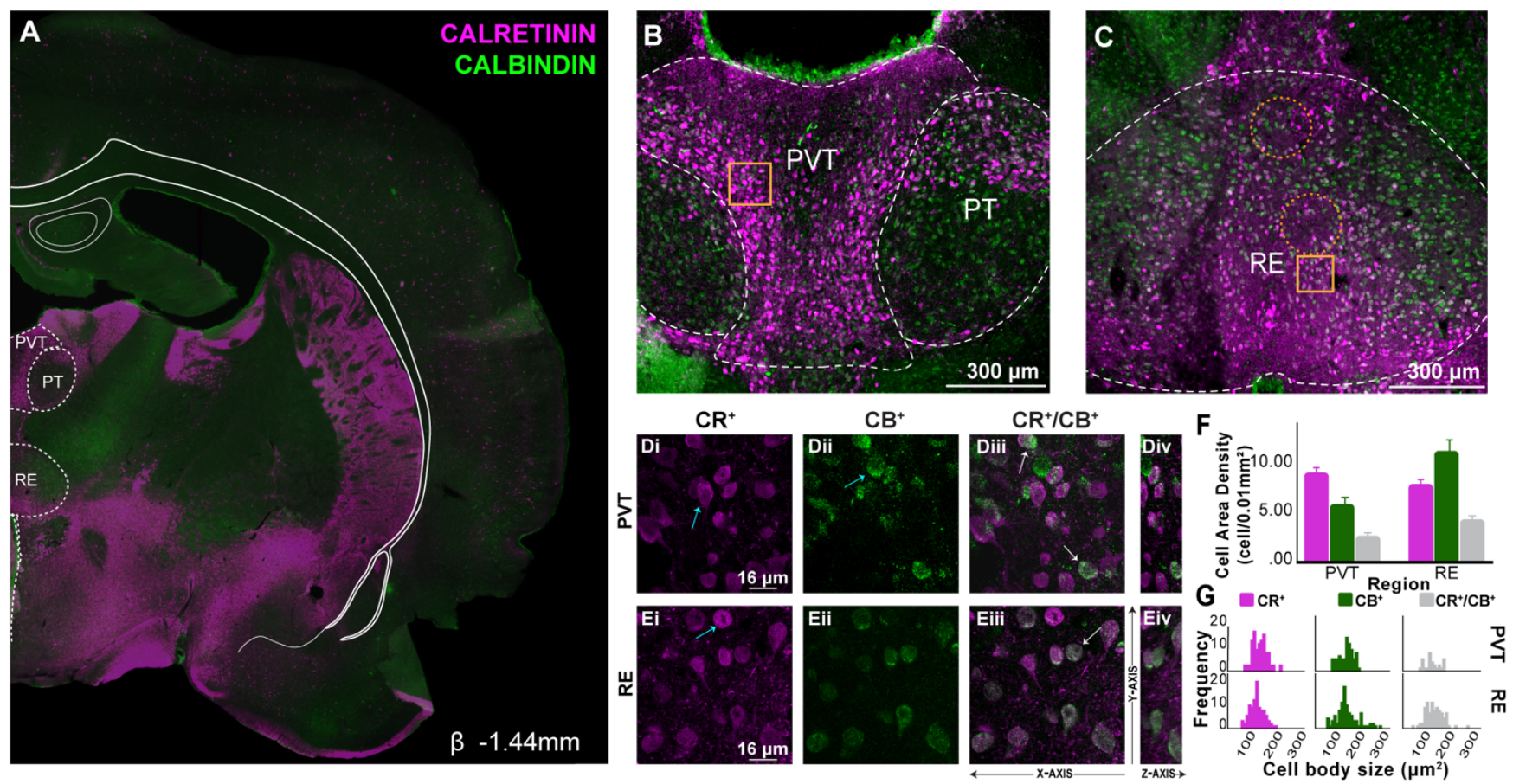

\section{Figure 2. $C R$ and $C B$ labeling in rostral midline thalamus}

A: Representative coronal section ( $\beta-1.44 \mathrm{~mm}$ ) showing immunofluorescent localization of $\mathrm{CR}^{+}$and $\mathrm{CB}^{+}$cell and fiber densities. Overlay shown adapted from Swanson (2018) to highlight midline thalamic structures. CR shown in magenta, $\mathrm{CB}$ in green.

B: Confocal image demonstrating distribution of $\mathrm{CR}^{+}$and $\mathrm{CB}^{+}$cells in PVT and PT. In PVT, CR was prominent in dorsolateral and ventromedial regions, and CB ventrally in PT. C: A similar but inversed distribution was observed in $\mathrm{RE}$ where $\mathrm{CR}^{+}$cells were prominent in ventrolateral and dorsomedial regions, while $\mathrm{CB}^{+}$cells were prominent laterally. Gold squares represent region of 60X magnification shown in inset. Orange dotted circles indicate regions where calcium binding protein cell expression is sparse or absent. Scale bar $=300 \mu \mathrm{m}$.

D: Confocal images illustrating $\mathrm{CR}^{+}\left(\mathrm{D}_{\mathrm{i}}\right), \mathrm{CB}^{+}\left(\mathrm{D}_{\text {ii) }}\right)$ and dual labeled $\mathrm{CR}^{+} / \mathrm{CB}^{+}\left(\mathrm{D}_{\text {iii }}\right)$ immunoreacted cell bodies in PVT. Three distinct cell populations were identified: $C^{+}$only cells $\left(\mathbf{D}_{\mathrm{i}}\right.$, blue arrow), $\mathrm{CB}^{+}$only cells $\left(\mathrm{D}_{\mathrm{ii}}\right.$, blue arrow) and dual $\mathrm{CR}^{+} / \mathrm{CB}^{+}$cell bodies ( $\mathrm{D}_{\mathrm{iii}}$, white arrows). The $Z$-axis from these optical sections are shown to the right $\left(\mathrm{D}_{\mathrm{iv}}\right)$. $\mathrm{E}$ : Confocal images in $\mathrm{RE}\left(\mathrm{E}_{\mathrm{i}}-\mathrm{E}_{\mathrm{iv}}\right)$. Scale bar $=16 \mu \mathrm{m}$.

F: Comparison of $\mathrm{CR}^{+}$and $\mathrm{CB}^{+}$cell area density in PVT and RE (cells $\left./ 0.01 \mathrm{~mm}^{2}\right)$ in rostral levels. Error bars represent SEM.

G: Frequency distribution of $\mathrm{CR}^{+}, \mathrm{CB}^{+}$and $\mathrm{CR}^{+} / \mathrm{CB}^{+}$immunoreacted cell body size $\left(\mu \mathrm{m}^{2}\right)$ in rostral PVT and $\mathrm{RE}$.

Abbreviations: $\beta$, bregma; $C B$, calbindin; $C R$, calretinin; PVT, paraventricular; PT, paratenial; RE, nucleus reuniens, SEM, standard error of the mean. 

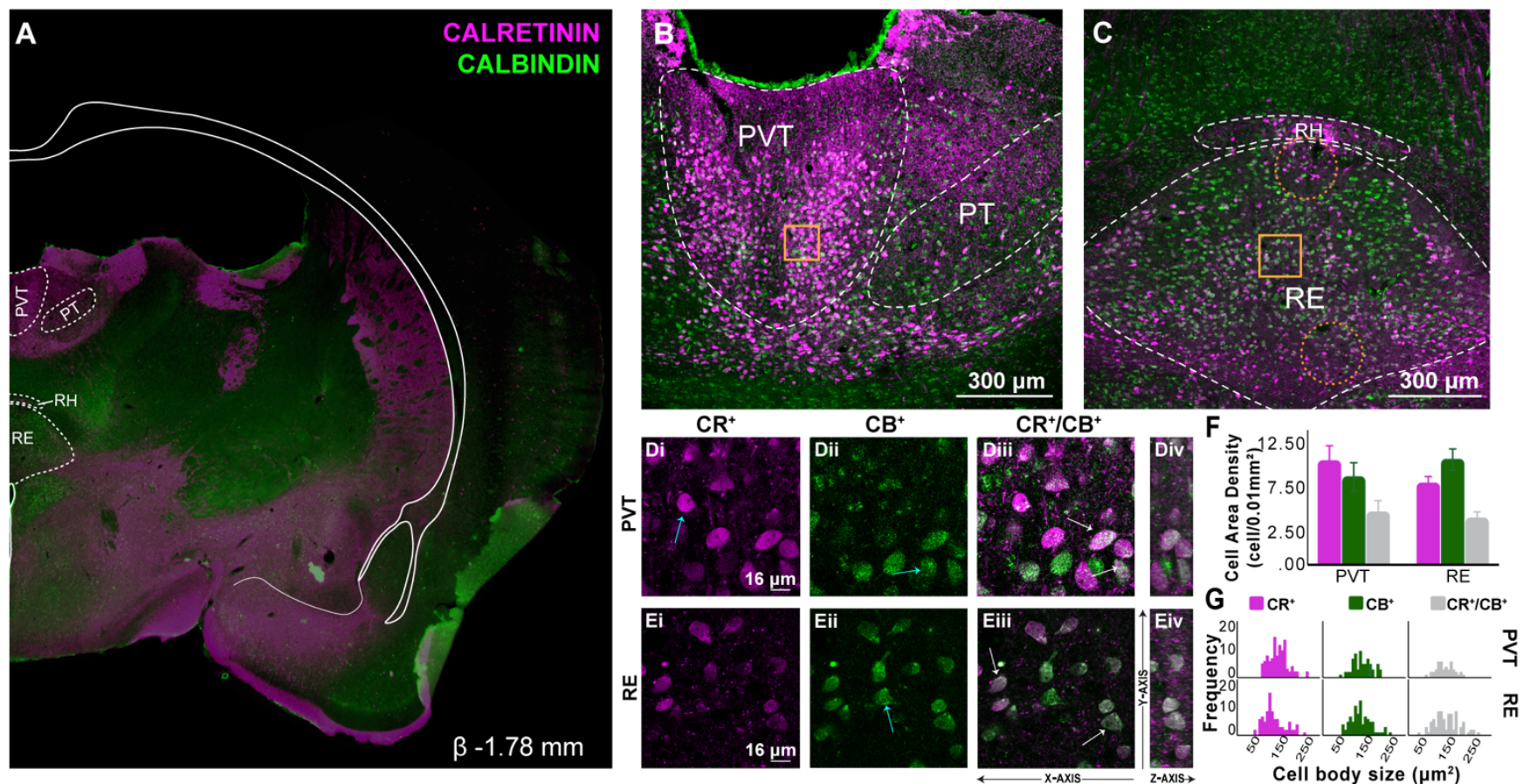

015

016

017

018

019

020

021

022

023

024

025

026

027

028

029

030

031

032

033

034

035

036

037

038

039

040

041

042

043

044

045

Figure 3. $C R$ and $C B$ labeling in mid levels of midline thalamus

A: Representative coronal section $(\beta-1.78 \mathrm{~mm})$ showing immunofluorescent localization of $\mathrm{CR}^{+}$and $\mathrm{CB}^{+}$cell and fiber densities in mid-levels of the rostro-caudal axis of the thalamus. Overlay shown adapted from Swanson (2018) to highlight midline thalamic structures. CR shown in magenta, CB in green. Fi, RSD and motor-sensory cortex layers missing from tissue section.

B: Confocal image demonstrating distribution of $\mathrm{CR}^{+}$and $\mathrm{CB}^{+}$in PVT and PT. Compared to rostral levels, $\mathrm{PVT} \mathrm{CR}^{+}$ and $\mathrm{CB}^{+}$cells re-distributed more ventral and laterally. $\mathrm{CR}^{+}$fibers were abundant in dorsal PVT and PT (below 3V).

C: In RE, a similar but inverse re-distribution was also observed, with $\mathrm{CR}^{+}$cells prominent ventral and laterally and $\mathrm{CB}^{+}$cells in dorsolateral regions. A zone of $\mathrm{CR}^{+}$fibers emerged ventromedially just above $3 \mathrm{~V}$. Gold squares represent regions of $60 \mathrm{X}$ magnification shown in inset. Orange dotted circles indicate regions in which there is sparse or no expression of calcium binding cells. Scale bar $=300 \mu \mathrm{m}$.

D: Confocal images illustrating $\mathrm{CR}^{+}\left(\mathrm{D}_{\mathrm{i}}\right), \mathrm{CB}^{+}\left(\mathrm{D}_{\mathrm{ii}}\right)$ and dual labeled $\mathrm{CR}^{+} / \mathrm{CB}^{+}\left(\mathrm{D}_{\text {iii }}\right)$ immunoreacted cell bodies in PVT. At this level, the same three calcium binding cell types were visualized: $C R^{+}$only cells $\left(D_{i}\right.$, blue arrow), CB ${ }^{+}$ only cells ( $D_{\text {ii }}$ blue arrow) and dual $C R^{+} / C B^{+}$cell bodies ( $D_{\text {iii, }}$ white arrows). The Z-axis from these optical sections are shown to the right $\left(\mathbf{D}_{\text {iv }}\right)$.
E: Confocal images in RE ( $\left.E_{i}-E_{i v}\right)$. Scale bar $=16 \mu m$.

F: Comparison of $\mathrm{CR}^{+}$and $\mathrm{CB}^{+}$cell area density in PVT and RE in mid-levels of midline thalamus (cells $/ 0.01 \mathrm{~mm}^{2}$ ).

G: Frequency distribution of $\mathrm{CR}^{+}, \mathrm{CB}^{+}$and $\mathrm{CR}^{+} / \mathrm{CB}^{+}$immunoreacted cell body size $\left(\mu \mathrm{m}^{2}\right)$ in $\mathrm{PVT}$ and $\mathrm{RE}$ at midlevels of the thalamus. Error bars represent SEM.

Abbreviations: $\beta$, bregma; CB, calbindin; CR, calretinin; PVT, paraventricular; PT, paratenial; RE, nucleus reuniens; $\mathrm{RH}$, rhomboid; Fi, fimbria of the hippocampus, RSD, retrosplenial dysgranular cortex, SEM, standard error of the mean; $3 \mathrm{~V}$, third ventricle. 

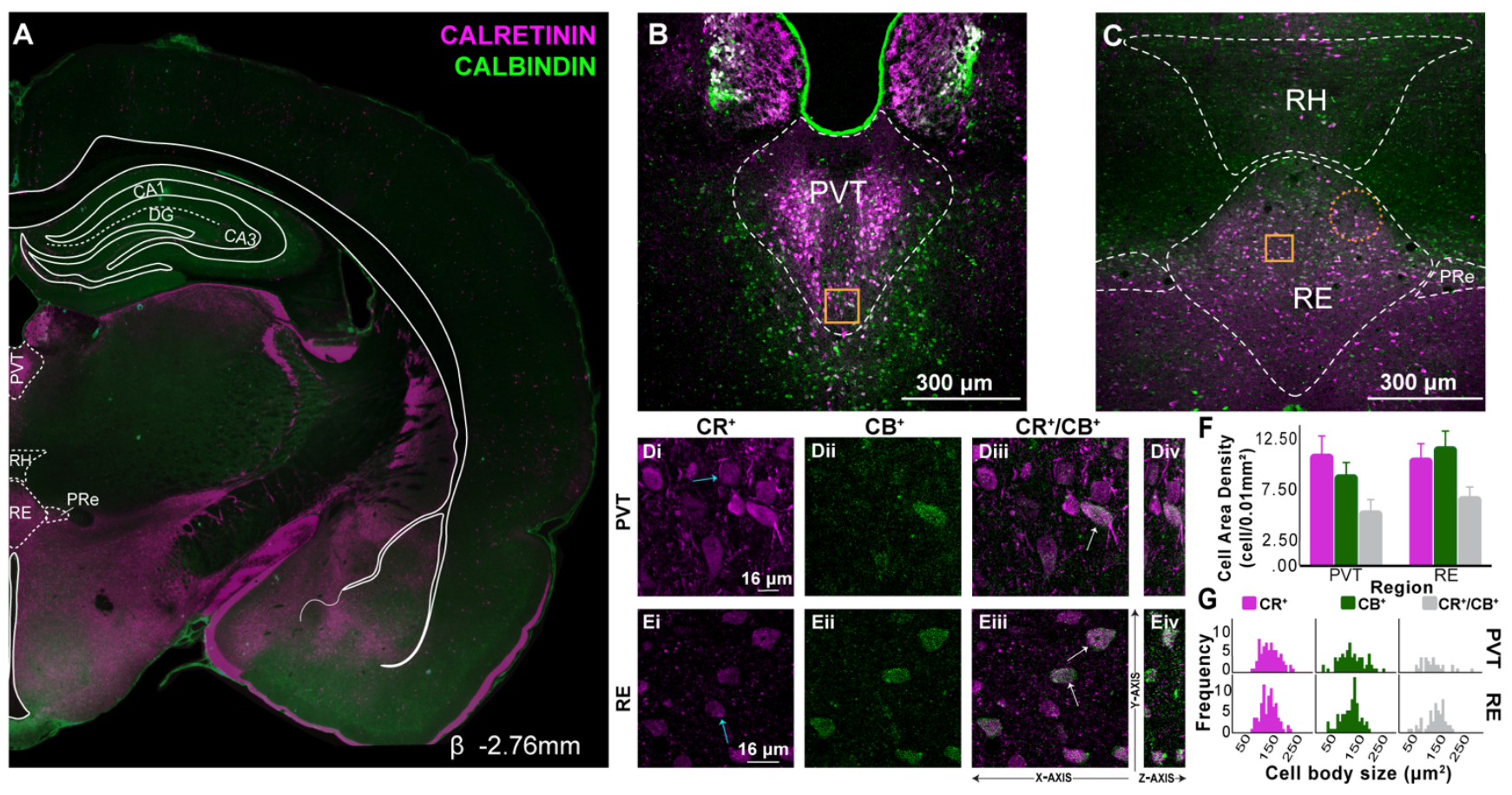

\section{Figure 4. $C R$ and $C B$ labeling in caudal midline thalamus}

A: Representative coronal section ( $\beta-2.76 \mathrm{~mm}$ ) showing immunofluorescent localization of $\mathrm{CR}^{+}$and $\mathrm{CB}^{+}$cell and fiber densities in caudal midline thalamus. Overlay shown adapted from Swanson (2018) to highlight midline thalamic structures. CR shown in magenta, CB in green.

B: Confocal image demonstrating distribution of $\mathrm{CR}^{+}$and $\mathrm{CB}^{+}$cells in PVT and PT caudally. In PVT, $\mathrm{CR}^{+}$cells clustered mediolaterally and $\mathrm{CB}^{+}$cells were predominantly seen in PVT ventral borders. $\mathrm{C}$ : In RE, $\mathrm{CB}^{+}$cells were prominent in dorsal and lateral borders, while $\mathrm{CR}^{+}$cells were observed more mediolaterally, often overlapping with $\mathrm{CB}^{+}$cells. $\mathrm{CR}^{+}$fibers continued to be abundant ventrally (above $3 \mathrm{~V}$ ). Gold squares represent region of $60 \mathrm{X}$ magnification shown in inset. Orange dotted circles indicate regions in which there is sparse or no expression of calcium binding cells. Scale bar $=300 \mu \mathrm{m}$.

D: Confocal images illustrating $C R^{+}\left(D_{i}\right), C B^{+}\left(D_{i i}\right)$ and dual labeled $\mathrm{CR}^{+} / \mathrm{CB}^{+}\left(\mathbf{D}_{\text {iii }}\right)$ immunoreacted cell bodies in PVT. As in previous levels, three cell types are visualized: $\mathrm{CR}^{+}$only cells $\left(\mathbf{D}_{\mathbf{i}}\right.$, blue arrow), $C B^{+}$only cells (not shown) and dual $\mathrm{CR}^{+} / \mathrm{CB}^{+}$cell bodies ( $\boldsymbol{D}_{\text {iii, }}$ white arrows). The Z-axis from these optical sections are shown to the right ( $D_{\text {iv }}$ ).

E: Confocal images in RE ( $\left.E_{i}-E_{i v}\right)$. Scale bar $=16 \mu m$.

F: Comparison of $\mathrm{CR}^{+}$and $\mathrm{CB}^{+}$cell area density in PVT and RE in caudal levels of the midline thalamus (cells $\left./ 0.01 \mathrm{~mm}^{2}\right)$. Error bars represent SEM.

G: Frequency distribution of $\mathrm{CR}^{+}, \mathrm{CB}^{+}$and $\mathrm{CR}^{+} / \mathrm{CB}^{+}$immunoreacted cell body size $\left(\mu \mathrm{m}^{2}\right)$ in caudal PVT and $\mathrm{RE}$.

Abbreviations: $\beta$, bregma; CA1, CA1 subfield of the hippocampus; CA3, CA3 subfield of the hippocampus; CB, calbindin; CR, calretinin; DG, dentate gyrus; PVT, paraventricular; PRe, perireuniens; RE, nucleus reuniens, $R H$, rhomboid, SEM, standard error of the mean. 

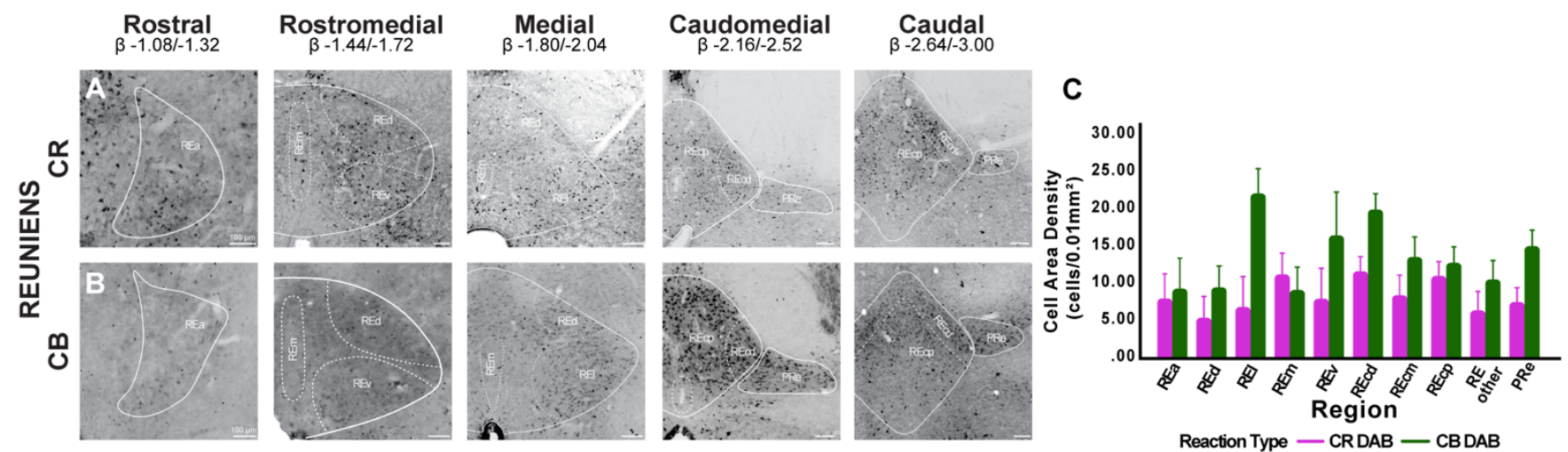

Figure 5. Distribution of $D A B C R^{+}$and $D A B C B^{+}$cells is not the same across all RE internal subdivisions

075

076

077

078

079

080

081

082

083

084

085

086

087

088

089

090

091

092

093

A: Brightfield images showing the distribution of $D A B C R^{+}$cells in $R E$ across the rostro-caudal axis of the thalamus. $\mathrm{CR}^{+}$cell area density varied depending on the subdivision of RE in which they were located.

B: Distribution of $\mathrm{DAB} C \mathrm{~B}^{+}$cells. When compared, $\mathrm{CR}^{+}$and $\mathrm{CB}^{+}$cell distribution in all RE's subregions and across the rostral to caudal levels did not appear to be the same. Overlay shown adapted from Swanson (2018) to highlight all RE internal subdivisions. Scale bar $=100 \mu \mathrm{m}$.

C: Comparison of $\mathrm{DAB} \mathrm{CR}{ }^{+}$and $\mathrm{DAB} \mathrm{CB}{ }^{+}$cell area density (cells $/ 0.01 \mathrm{~mm}^{2}$ ) in all subdivisions of RE across the rostro-caudal axis. $\mathrm{CB}^{+}$cell densities were higher than $\mathrm{CR}^{+}$cell densities (except REm). Additionally, REl, REv and REcd subdivisions exhibited large $\mathrm{CB}^{+}$cell densities compared to other RE subregions. A moderate size effect was found for $\mathrm{CB}^{+}$cell area density across all levels and RE subdivisions (Hedges' $d=0.32$ ).

Abbreviations: $\beta$, bregma; CB, calbindin; CR, calretinin; DAB, 3,3'-Diaminobenzidine; PRe, perireuniens, RE, nucleus reuniens of the thalamus, REa, reuniens rostral division anterior part; REd, reuniens rostral division dorsal part; REI, reuniens rostral division lateral part; REm, reuniens rostral division median part; REv, reuniens rostral division ventral part; REcm, reuniens caudal division median part; REcd, reuniens caudal division dorsal part; REcp, reuniens caudal division posterior part. 
094

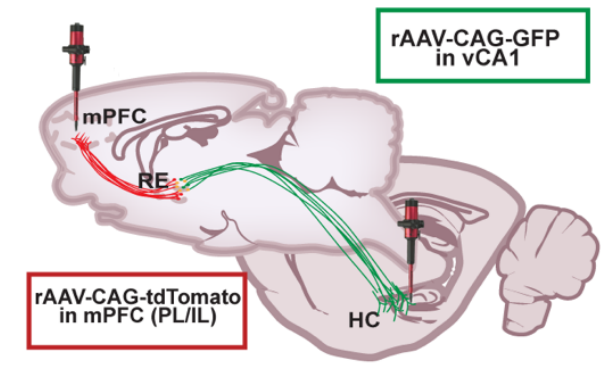

Di

CALRETININ

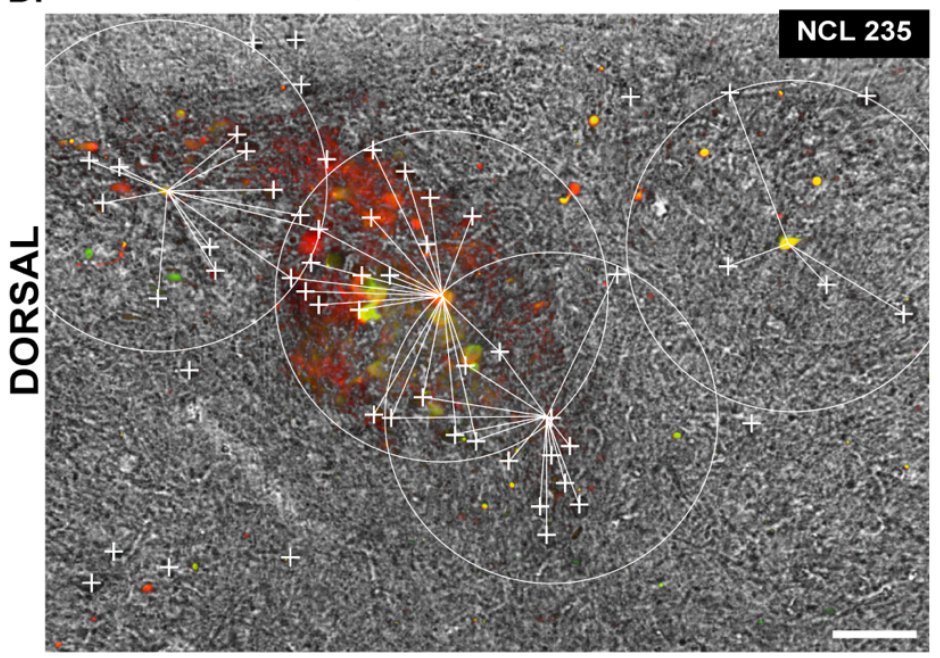

Dii

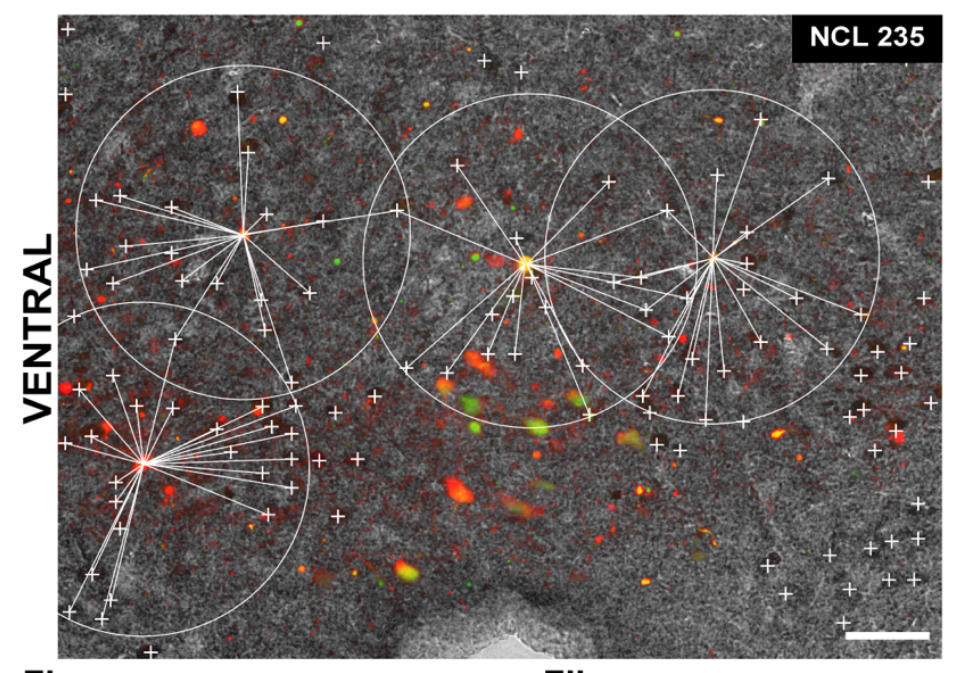

$\mathbf{F i}$

DAB CR+ Cells

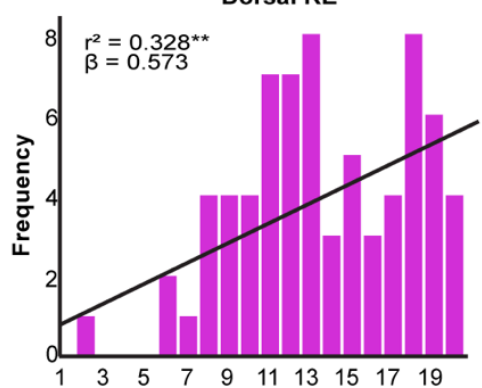

Distance within $100 \mu \mathrm{m}$ Radius

Distance within $100 \mu \mathrm{m}$ Radius
B

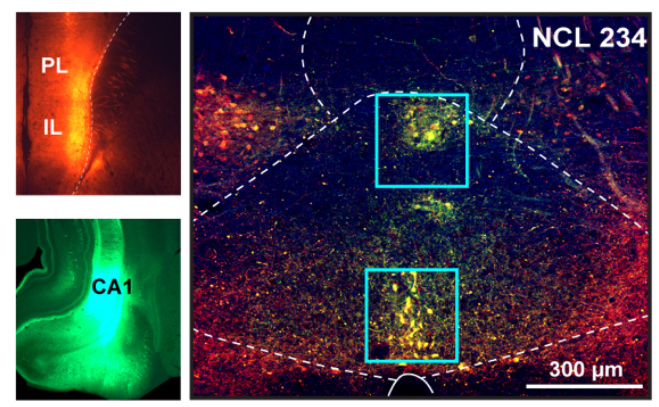

Ei
C

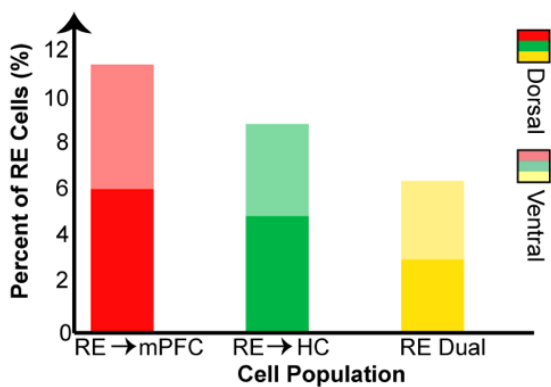

CALBINDIN

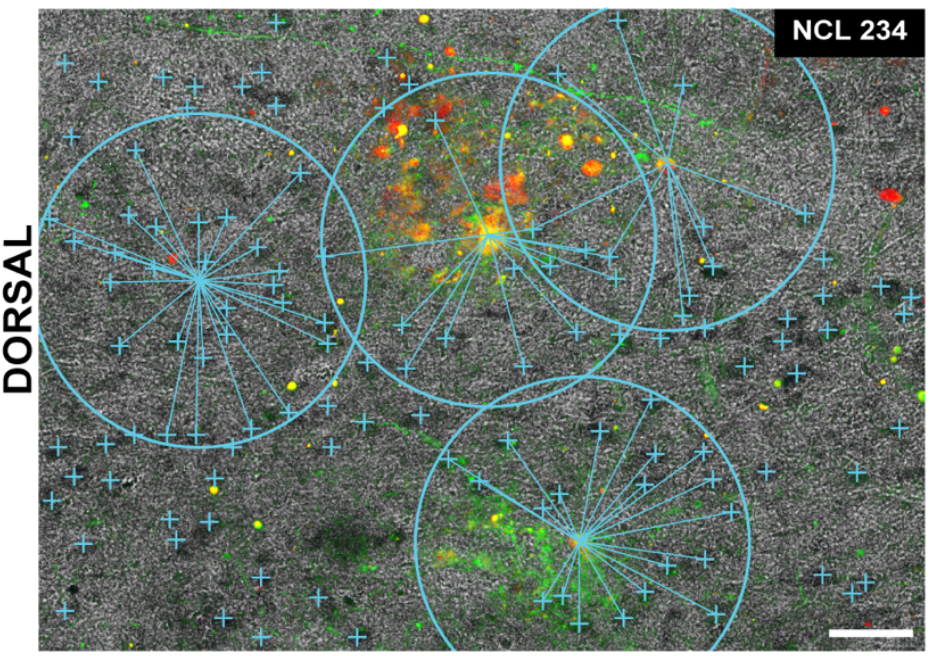

Eii

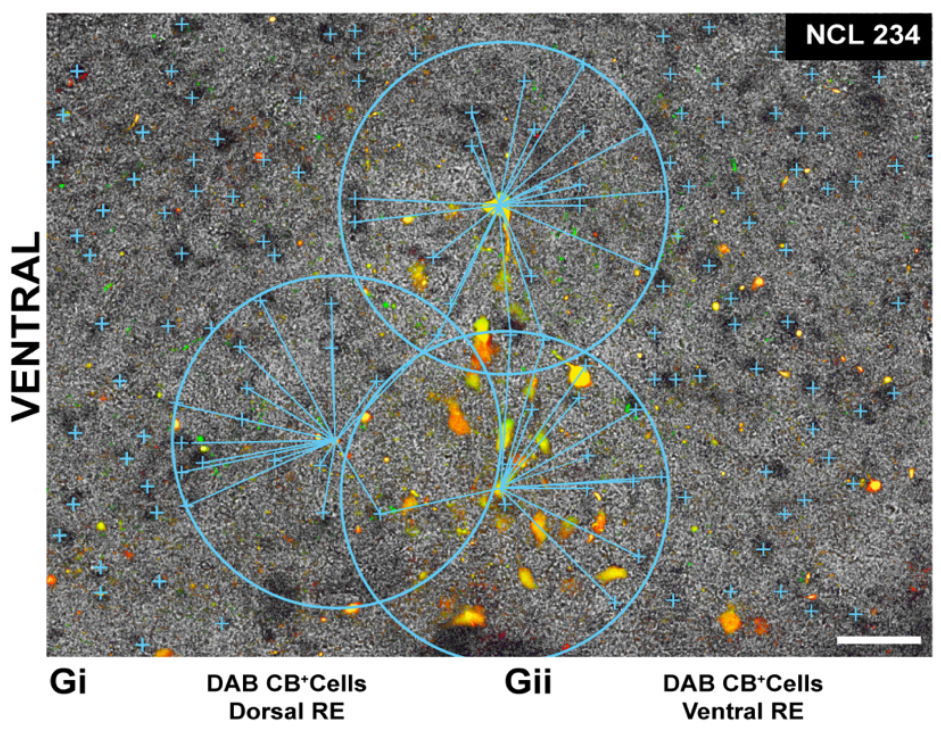

Ventral RE

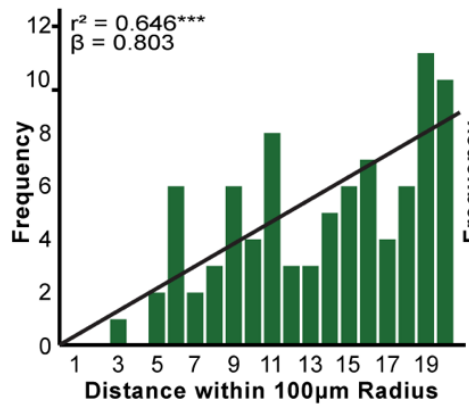

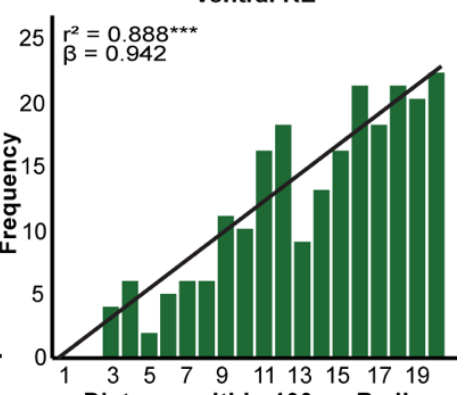

Distance within $100 \mu \mathrm{m}$ Radius 
bioRxiv preprint doi: https://doi.org/10.1101/2020.07.21.214973; this version posted July 21, 2020. The copyright holder for this preprint (which

was not certified by peer review) is the author/funder, who has granted bioRxiv a license to display the preprint in perpetuity. It is made available under aCC-BY-NC-ND 4.0 International license.

CALCIUM BINDING PROTEINS IN MIDLINE THALAMUS

095

096

097

098

099

100

101

102

103

104

105

106

107

108

109

110

111

112

113

114

115

116

117

118

119

120

121

\section{Figure 6. Dual-site mPFC-HC RE projecting cells are not $\mathrm{CB}^{+}$or $\mathrm{CR}^{+}$cells}

A: Experimental design. Paired bilateral injections of rAAV-CAG-tdTomato and rAAV-CAG-GFP delivered in mPFC and $\mathrm{HC}$.

B: Injections' spread was confined to PL/IL layer V/VII (top left) and vCA1 (bottom left). Retrogradely dual mPFC-HC projecting cells consistently clustered in dorsal and ventral aspects of RE in rostromedial levels (right). Blue squares represent regions in which clusters were found and further analyzed. Scale bar $=300 \mu \mathrm{m}$.

C: Percentage of retrogradely labeled RE to MPFC, REto vCA1 and dual mPFC-HC projecting neurons in RE dorsal and ventral regions of interest. All percentages are over total number of DAPI cells.

D-E: Merged captures of immunofluorescent RE dual labeled cells $\left(\mathbf{D}_{\mathrm{i}}-\mathrm{E}_{\mathrm{ii}}\right)$ and $\mathrm{RE} \mathrm{DAB} C \mathrm{R}^{+}\left(\mathbf{D}_{\mathrm{i}}, \mathbf{D}_{\mathrm{ii}}\right)$ or $\mathrm{DAB} C \mathrm{~B}^{+}$ $\left(E_{i}, E_{i i}\right)$ cell bodies in dorsal and ventral RE. For process see Fig. S1. No dual labeling between dual mPFC-HC projecting cells and $\mathrm{CR}^{+}$or $\mathrm{CB}^{+}$cells in $\mathrm{RE}$ was observed. The relative distance between the center of RE dual labeled cells (yellow) and CR +DAB cells (marked with white '+' signs) and/or CB+ DAB cells (marked with cyan '+' signs) within a $100 \mu \mathrm{m}$ radius was measured using FIJI Image $\mathrm{J}$. Scale bar $=50 \mu \mathrm{m}$.

F-G: Frequency distribution of $\mathrm{DAB} \mathrm{CR}^{+}$and $\mathrm{CB}^{+}$cell counts in $\mathrm{RE}$ dorsal and ventral $\left(\mathrm{F}_{\mathrm{i}}-\mathbf{G}_{\mathrm{iii}}\right)$ regions relative to radius distance ( $5 \mu \mathrm{m}$ bins) from $R E$ dual (yellow) labeled cells. The number of $D A B C R^{+}$and $D A B C B^{+}$cells from $R E$ dual labeled cells increased as a function of distance as shown by the linear regression line (black lines over histograms). Asterisks indicate significance: ${ }^{* *} p<.01 ;{ }^{* * *} p<.001$

Abbreviations: rAAV, retrograde adeno-associated virus; CA1, CA1 subfield of the hippocampus; CAG, chicken beta-Actin promoter; $\mathrm{CB}$, calbindin; CR, calretinin; DAB, 3,3'-Diaminobenzidine; DAPI, 4',6-Diamidino-2-phenylindole dihydrochloride; GFP, green fluorescent protein; HC, hippocampus; IL, infralimbic cortex; mPFC, medial prefrontal cortex; PL, prelimbic cortex; tdTomato, red fluorescent protein; vCA1, ventral CA1. 
A

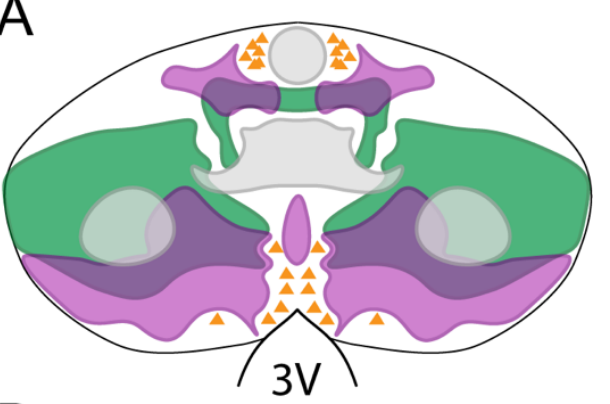

B

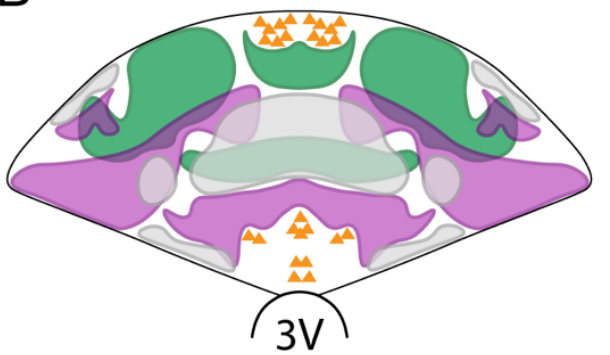

C

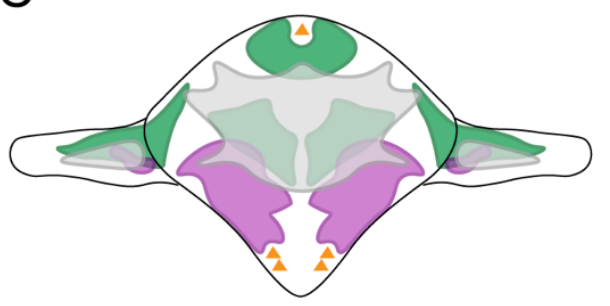

$$
\widehat{3 V}
$$

$\begin{array}{ll}\mathrm{CB}^{+} & \mathrm{RE} \text { dual-projecting } \\ \text { cells (mPFC \& vCA1) }\end{array}$

Figure 7. Topographical localization of $\mathrm{CR}$ and $\mathrm{CB}$ cell zones relative to dual mPFC-vHC projecting cells within RE

Schematic representation of the distribution of $\mathrm{CR}^{+}$and $\mathrm{CB}^{+}$cells in $\mathrm{RE}$ across (A) rostral, (B) medial, and (C) caudal levels. Colored areas represent zones where $\mathrm{CR}^{+}$(light magenta) and $\mathrm{CB}^{+}$(green) cells are concentrated. Intense magenta color represent regions in which $\mathrm{CB}$ and $\mathrm{CR}$ are in the same region, but do not overlap. Gray regions depict zones with dual labeled $\mathrm{CR}^{+} / \mathrm{CB}^{+}$cells are predominantly seen. Yellow triangles represent dual mPFC-HC projecting cells. Overlay shown adapted from Swanson (2018).

Abbreviations: CB, calbindin; CR, calretinin; mPFC, medial prefrontal cortex; RE, nucleus reuniens; vHC, ventral hippocampus; vCA1, ventral CA1; 3V, third ventricle. 